\title{
Structural Foam-Core Panels in Northwest HUD-Code Manufactured Housing: A Preliminary Assessment of Opportunities and Obstacles
}

\author{
D.L. Durfee
}

A.D. Lee

Stephen A. Onisko

July 1993

Prepared for the Bonneville Power Administration

Under a Related Services Agreement with the U.S. Department of Energy

Contract DE-AC06-76RLO 1830

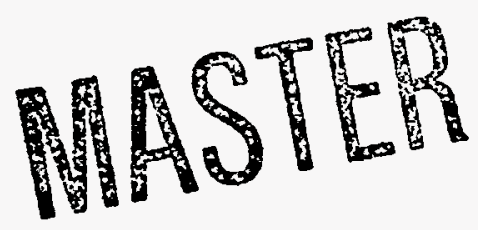




\section{DISCLAIMER}

This report was prepared as an account of work sponsored by an agency of the United States Government. Neither the United States Government nor any agency thereof, nor any of their employees, make any warranty, express or implied, or assumes any legal liability or responsibility for the accuracy, completeness, or usefulness of any information, apparatus, product, or process disciosed, or represents that its use would not infringe privately owned rights. Reference herein to any specific commercial product, process, or service by trade name, trademark, manufacturer, or otherwise does not necessarily constitute or imply its endorsement, recommendation, or favoring by the United States Government or any agency thereof. The views and opinions of authors expressed herein do not necessarily state or reflect those of the United States Government or any agency thereof. 


\section{DISCLAIMER}

\section{Portions of this document may be illegible in electronic image products. Images are produced from the best available original document.}




\section{SUMMARY}

The Pacific Northwest Laboratory (PNL) conducted this study for the Bonneville Power Administration (Bonneville) of the U.S. Department of Energy (DOE). The purpose of this study was to investigate the possible use of structural foam-core building panels in manufactured housing. With the initiation of the Bonnevillesponsored Manufactured-Housing Acquisition Program (MAP) on April 1, 1992, the energy efficiency requirements for Pacific Northwest manufactured homes have increased dramatically. One focus of MAP is the amount of glazing area per home. Previous regional energy-efficiency programs, such as Super Good Cents (SGC), limited glazing area because higher amounts of glazing can compromise a building's thermal performance. MAP allows unlimited glazing but requires the use of expensive vinyl-framed, argon-gas-filled, low-emissivity-coated windows. Structural foam-core panels (foam panels) consist of a rigid insulating foam core sandwiched between two structural facings. They provide superior thermal performance that might allow the use of less-expensive windows, larger window area, or less insulation in energy-efficient manufactured housing.

This study initially reviews foam panel materials, fabrication processes, and construction techniques and details. Types of foam include expanded polystyrene (EPS), extruded polystyrene (XEPS), urethane, and polyisocyanurate. Typical structural facings used are either panelized wood or steel. Panel fabrication is either conducted with an adhesive applied to a pre-cut foam core then cold pressed between the facings, or the foam is poured into pre-spaced facings and the foam cures to bond to the facings. Foam panel construction techniques are distinctive and are included in this report.

Foam panel cost would be a significant factor for the manufactured housing industry because the industry is cost conscious. Foam panel cost is a function of the foam type, foam thickness, facing materials, volume ordered, and the foam panel plant production capacity and utilization. Table S.1 presents estimated costs, based on real-world data, for a fully finished standardized wall ( 40 foot wide by 8 foot high) of various construction types. The materials and labor costs for foam panel construction are comparable to costs for "stick-built" construction. However, the capital and indirect costs resulting from inventory and partial capacity utilization make foam panels more expensive. 
The "Total Adjusted Cost" in Table S.1 shows the effect of reducing foam panel inventory and increasing capacity utilization to be comparable with site-built and factory-framed construction. If the foam panel manufacturers supplied panels to the HUD-code industry, it is reasonable to assume the plant would be running at full capacity to meet the demand. Under these conditions, foam panels appear to be cost competitive. Recent surges in lumber prices may also have a significant effect on foam panel cost effectiveness.

TABLE S.1. Cost Comparison for Various Wall Construction Types

\begin{tabular}{|c|c|c|c|c|c|}
\hline Cost Component & $\begin{array}{l}\text { 4" Wall, } \\
\text { Site-Built, } \\
\text { MFR } 1\end{array}$ & $\begin{array}{l}4^{\prime \prime} \text { Wall, } \\
\text { Factory } \\
\text { Framed, } \\
\text { MFR } 2\end{array}$ & $\begin{array}{l}4^{\text {" Wall, }} \\
\text { Factory } \\
\text { Framed, } \\
\text { MFR } 3\end{array}$ & $\begin{array}{l}\text { 4" Wall, } \\
\text { Foam } \\
\text { Panel, } \\
\text { MFR } 4\end{array}$ & $\begin{array}{l}4 " \text { Wall, } \\
\text { Foam } \\
\text { Panel, } \\
\text { MFR } 5\end{array}$ \\
\hline Material & 970 & 970 & 940 & 1060 & 1090 \\
\hline Labor & 380 & 330 & 380 & 440 & 450 \\
\hline Capital \& Indirect & 0 & 60 & 40 & 600 & 150 \\
\hline Total Cost & $\$ 1350$ & $\$ 1360$ & $\$ 1360$ & $\$ 2100$ & $\$ 1690$ \\
\hline $\begin{array}{l}\text { Total Adjusted } \\
\text { Cost }\end{array}$ & $\$ 1350$ & $\$ 1370$ & $\$ 1360$ & $\$ 1600$ & $\$ 1590$ \\
\hline
\end{tabular}

In addition to cost data, this study presents the results from a survey conducted with three regional foam panel manufacturers. A questionnaire was administered to collect information concerning their company, customers, products and services offered, manufacturing process, and experience and interest in the manufactured housing industry. None of the manufacturers was aware of prior or current use of foam panels in the manufactured housing industry, but they were very interested in penetrating the market. The advantages and disadvantages perceived by the foam panel manufacturers are listed in Table S.2.

(a) Personal communication with Mike Mullens of the University of Central Florida, Industrial Engineering Department. March 19, 1993. 
TABLE S.2. Foam Panel Manufacturers Perceived Advantages and Disadvantages of Using the Foam Panel Technology in HUD-Code Housing

\begin{tabular}{||l|l||}
\hline \hline Perceived Advantages & Perceived Disadvantages \\
\hline \hline $\begin{array}{l}\text { The HUD-code market is large and } \\
\text { growing and is unpenetrated by } \\
\text { this technology }\end{array}$ & $\begin{array}{l}\text { Panel manufacturers are not } \\
\text { familiar with the HUD-code } \\
\text { industry and building techniques }\end{array}$ \\
$\begin{array}{l}\text { Foam panel technology is } \\
\text { complementary to the quick } \\
\text { construction time and low labor } \\
\text { costs }\end{array}$ & - $\begin{array}{l}\text { The building industry is resistant } \\
\text { to change }\end{array}$ \\
$\begin{array}{l}\text { Production occurs year-round and } \\
\text { will require consistently large } \\
\text { quantities of panels }\end{array}$ & $\begin{array}{l}\text { Panels are not thought to be } \\
\text { cost competitive at this time }\end{array}$ \\
\hline
\end{tabular}

Six regional HUD-code producers, representing a range of markets from the low-end through the more expensive high-end, were also surveyed. Foam panel technical specifications were presented and a questionnaire was administered to obtain initial impressions of the production and design impacts of using foam panels for manufactured homes. Some fundamental concerns were expressed by each manufacturer including structural effects during transportation, panel weight, and the building industry's resistance to change. Advantages and disadvantages of integrating the panel technology into the manufactured housing industry, as perceived by the manufacturers, are listed in Table S.3. 
TABLE S.3. HUD-Code Manufacturers Perceived Advantages and Disadvantages of Using the Foam Panel Technology in HUD-Code Housing

\begin{tabular}{|c|c|}
\hline Perceived Advantages & Perceived Disadvantages \\
\hline $\begin{array}{l}\text { Wood alternative } \\
\text { Allow the use of less expensive } \\
\text { windows } \\
\text { - } \quad \text { Increase interior volume } \\
\text { - } \quad \text { Labor savings } \\
\text { Production line oriented } \\
\text { Does not conflict with current } \\
\text { designs } \\
\text { Reduce infiltration sealing and } \\
\text { caulking } \\
\text { Thermal performance } \\
\text { Improved quality control }\end{array}$ & 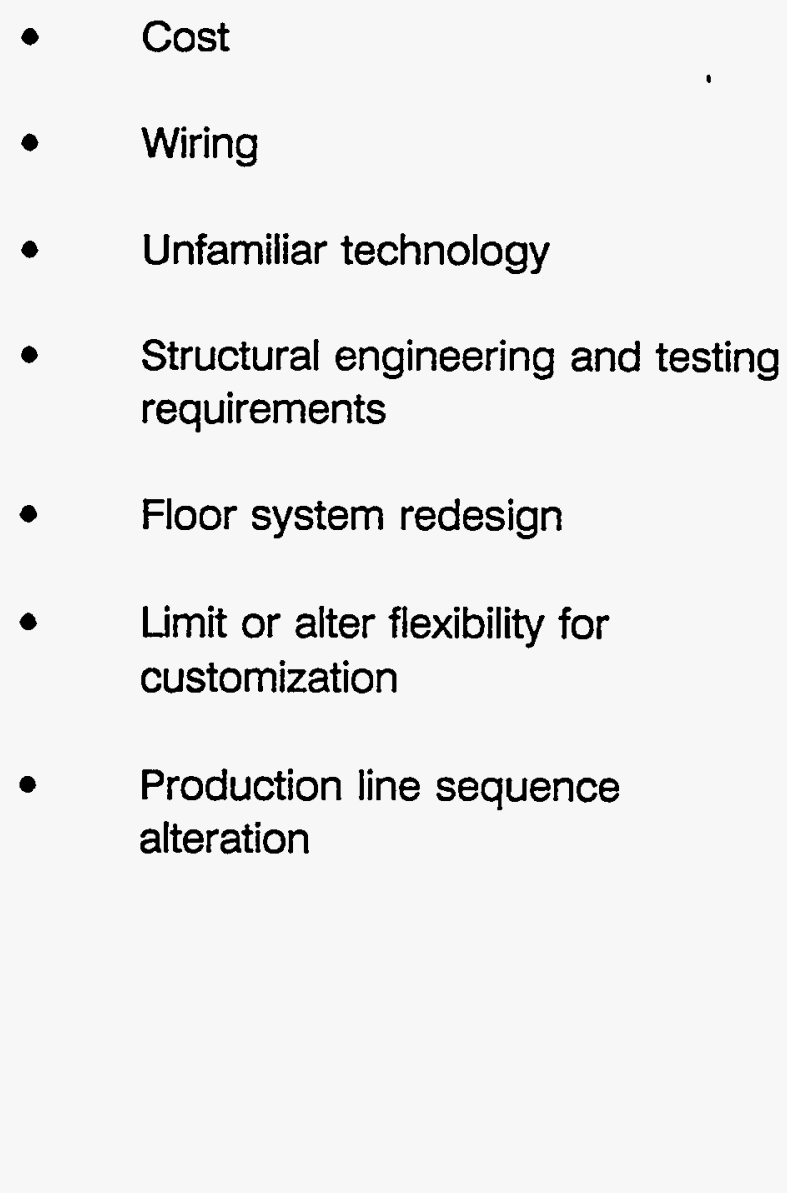 \\
\hline
\end{tabular}

The possibility of conducting a demonstration project to fully exploit the use of foam panels in manufactured housing was discussed with each manufacturer PNL. surveyed. One option presented was a Cooperative Research and Development Agreement (CRADA), which is an agreement between a national laboratory, such as PNL, and one or more non-federal participants. Two of the three foam panel manufacturers surveyed expressed interest in a CRADA collaboration, such as supplying materials and their expertise. The HUD-code manufacturers were reluctant to even consider participating in a demonstration project. Some of the reasons for their hesitation include the lack of familiarity with the technology, cost, structural integrity, and the associated risk. 
Despite their initial reluctance to participate in a demonstration project, soaring lumber prices and other factors may provide enough reason for HUD-code home manufacturers to consider seriously participating in a demonstration that would answer their questions about using foam panels in this industry. 


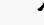




\section{CONTENTS}

SUMMARY $\ldots \ldots \ldots \ldots \ldots \ldots \ldots \ldots \ldots \ldots \ldots \ldots \ldots \ldots \ldots \ldots \ldots \ldots$ iii

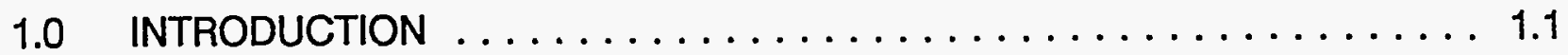

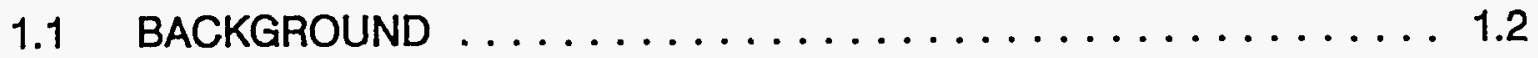

1.2 STRUCTURAL FOAM-CORE PANELS $\ldots \ldots \ldots \ldots \ldots \ldots \ldots 1.2$

2.0 FOAM PANEL MATERIALS AND CONSTRUCTION $\ldots \ldots \ldots \ldots \ldots \ldots 2.1$

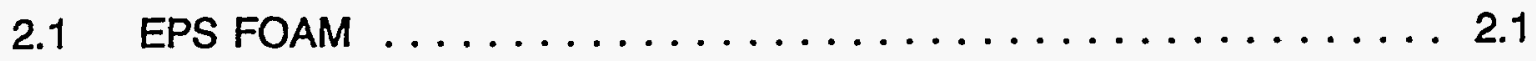

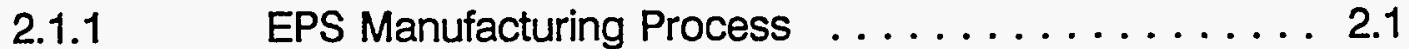

$2.1 .2 \quad$ EPS Thermal Properties $\ldots \ldots \ldots \ldots \ldots \ldots \ldots .2 .2$

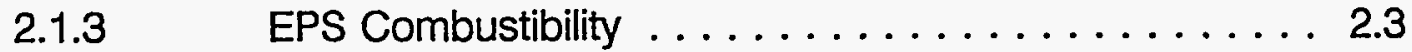

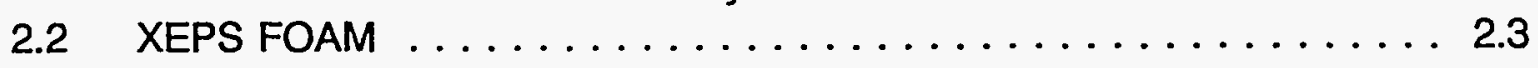

2.2.1 XEPS Manufacturing Process $\ldots \ldots \ldots \ldots \ldots \ldots 2.4$

2.2.2 XEPS Thermal Properties $\ldots \ldots \ldots \ldots \ldots \ldots \ldots 2.4$

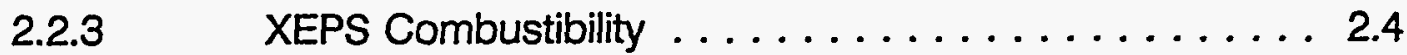

2.3 URETHANE \& POLYISOCYANURATE FOAM . . . . . . . . 2.5

2.3.1 Urethane \& Polyisocyanurate Manufacturing Process . . 2.5

2.3.2 Urethane \& Polyisocyanurate Thermal Properties . . . 2.5

2.3.3 Urethane \& Polyisocyanurate Combustibility . . . . 2.6

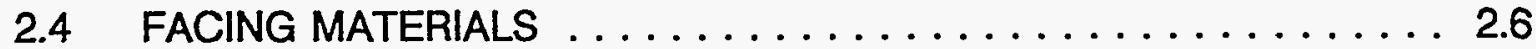

2.5 CONSTRUCTION TECHNIQUES $\ldots \ldots \ldots \ldots \ldots \ldots \ldots \ldots \ldots 2.7$

2.5.1 Panel to Panel Connection Methods . . . . . . . . . 2.7

2.5 .2 Construction Details . . . . . . . . . . . . 2.10

2.5 .3 Wiring $\ldots \ldots \ldots \ldots \ldots \ldots \ldots \ldots \ldots \ldots \ldots \ldots \ldots \ldots \ldots \ldots \ldots \ldots \ldots \ldots \ldots \ldots .12$

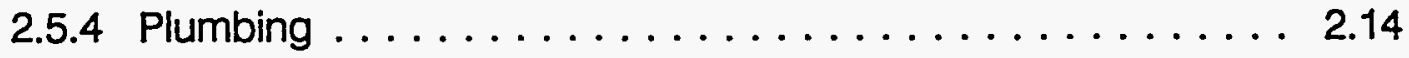

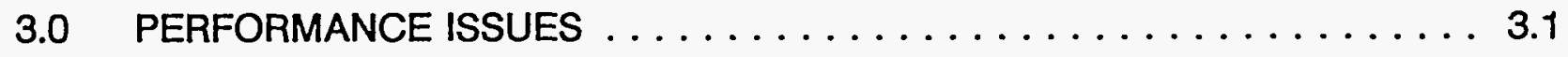

3.1 STRUCTURAL INTEGRITY $\ldots \ldots \ldots \ldots \ldots \ldots \ldots \ldots \ldots .1$

3.2 QUALITY CONTROL $\ldots \ldots \ldots \ldots \ldots \ldots \ldots \ldots \ldots \ldots \ldots .2$

3.3 INSECTS AND RODENTS $\ldots \ldots \ldots \ldots \ldots \ldots \ldots \ldots \ldots \ldots .2$

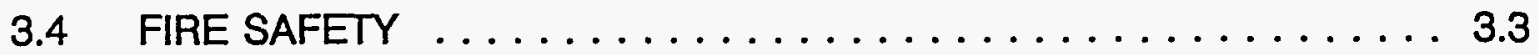

3.5 MANUFACTURER WARRANTIES $\ldots \ldots \ldots \ldots \ldots \ldots \ldots \ldots .3$

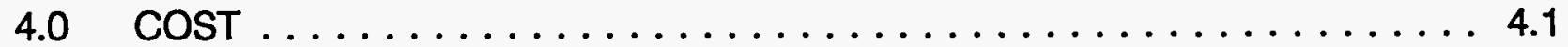

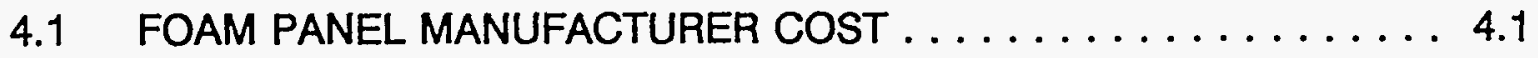

4.2 FOAM PANEL COST COMPARISON $\ldots \ldots \ldots \ldots \ldots \ldots \ldots \ldots .2$

4.3 POTENTIAL FOAM PANEL COST REDUCTIONS $\ldots \ldots \ldots \ldots \ldots 4.5$

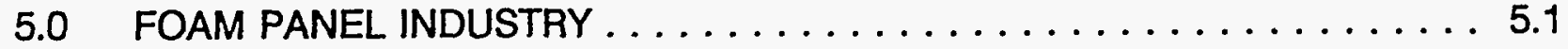

5.1 INDUSTRY ASSOCIATIONS $\ldots \ldots \ldots \ldots \ldots \ldots \ldots \ldots \ldots \ldots .1$

5.2 MARKET POTENTIAL ................... 5.3

5.3 NATIONAL FOAM PANEL MANUFACTURERS $\ldots \ldots \ldots \ldots \ldots .4$ 
6.0 REGIONAL FOAM PANEL MANUFACTURER SURVEY $\ldots \ldots \ldots \ldots \ldots .6 .1$

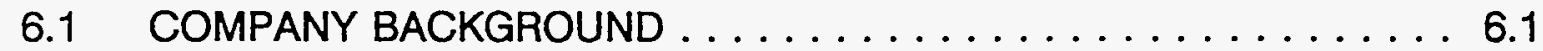

6.2 SALES $\ldots \ldots \ldots \ldots \ldots \ldots \ldots \ldots \ldots \ldots \ldots \ldots \ldots \ldots \ldots \ldots \ldots \ldots \ldots .2$

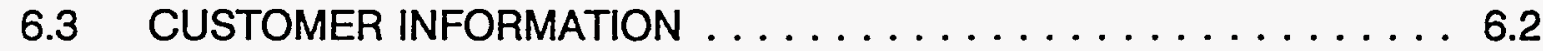

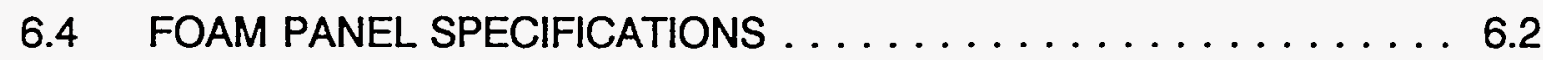

6.5 MANUFACTURING \& TRANSPORTATION $\ldots \ldots \ldots \ldots \ldots \ldots . . . \ldots$

. 6.6 HUD-CODE MANUFACTURED HOUSING INFORMATION . . . . . 6.3

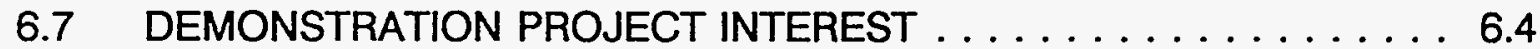

7.0 REGIONAL HUD-CODE MANUFACTURER SURVEY $\ldots \ldots \ldots \ldots \ldots 7.1$

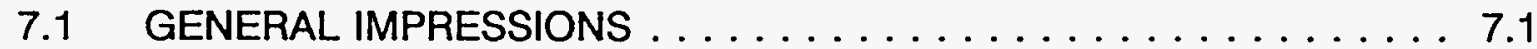

7.2 FUNDAMENTAL CONCERNS $\ldots \ldots \ldots \ldots \ldots \ldots \ldots \ldots \ldots \ldots .2$

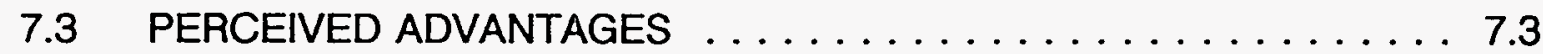

7.4 PERCEIVED DISADVANTAGES $\ldots \ldots \ldots \ldots \ldots \ldots \ldots \ldots \ldots$

7.5 BUILDING COMPONENT FEASIBILITY $\ldots \ldots \ldots \ldots \ldots \ldots .7$

7.6 MANUFACTURING OBSTACLES $\ldots \ldots \ldots \ldots \ldots \ldots \ldots \ldots . . \ldots \ldots$

7.7 DEMONSTRATION PROJECT FEASIBILITY $\ldots \ldots \ldots \ldots \ldots \ldots .8$

8.0 FOAM PANEL RESEARCH $\ldots \ldots \ldots \ldots \ldots \ldots \ldots \ldots \ldots \ldots . \ldots \ldots . \ldots \ldots$

8.1 DOE'S ENERGY-EFFICIENT INDUSTRIALIZED HOUSING PROJECT 8.1

8.1.1 Penn Lyon Homes PEER Visit . . . . . . . . . . . 8.1

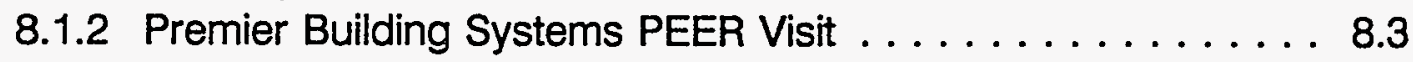

8.1.3 Side-By-Side Evaluation $\ldots \ldots \ldots \ldots \ldots \ldots \ldots \ldots \ldots . \ldots \ldots$

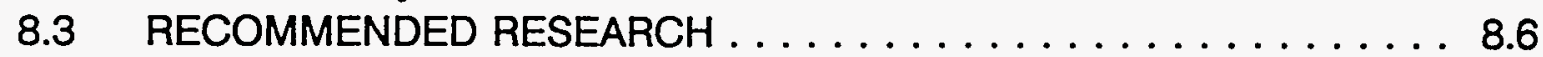

9.0 CONCLUSION . . . . . . . . . . . . . . . . . . . . 9.1

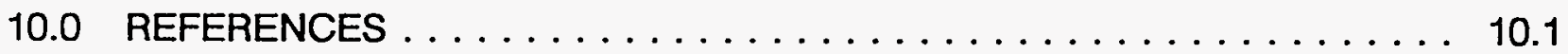




\section{FIGURES}

1.1 Analogy of a Foam Panel With an I-Beam $\ldots \ldots \ldots \ldots \ldots \ldots \ldots$

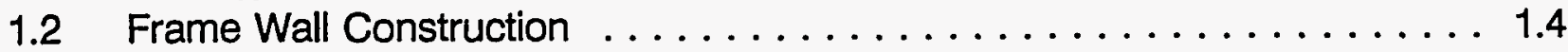

1.3 Foam Panel Wall Construction . . . . . . . . . . . . . . . 1.4

1.41992 Framing Lumber Market Price and Index . . . . . . . . . . . 1.5

2.1 Double Spline Panel Connection . . . . . . . . . . . . . . 2.8

2.2 Framing Member Spline Panel Connection . . . . . . . . . . . . 2.8

2.3 Thermally Broken Spline Panel Connection . . . . . . . . . . . . . 2.9

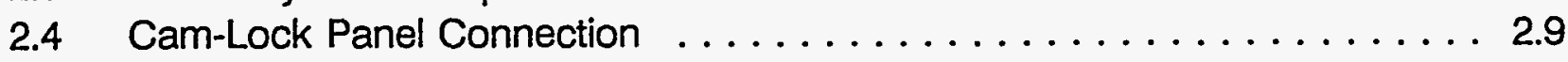

2.5 Foam Panel Ridge Construction Detail . . . . . . . . . . . . . . . . 2.10

2.6 Foam Panel Roof to Wall Construction Detail . . . . . . . . . . . . 2.10

2.7 Foam Panel Wall Corner Construction Detail . . . . . . . . . . . . . 2.11

2.8 Foam Panel Wall to Floor Construction Detail . . . . . . . . . . . 2.11

2.9 Typical Location of Foam Panel Electrical Chases . . . . . . . . . . . 2.12

2.10 Foam Panel Electrical Box Detail . . . . . . . . . . . . . . 2.13

2.11 Foam Panel Plumbing Chase Detail . . . . . . . . . . . . . . . 2.14

5.1 Geographic Location of Foam Panel Manufacturers . . . . . . . . . . 5.2

7.1 Additional Double Glazing Area Achievable With a 6" Panel Wall . . . . . . 7.5

7.2 Vaulted Truss Roof Section . . . . . . . . . . . . . . . 7.5

7.3 Manufactured Housing Transverse Floor Section $\ldots \ldots \ldots \ldots \ldots \ldots 7.7$

8.1 R-Control Foam Panel House, Olympia, WA . . . . . . . . . . . . . 8.4

8.2 R-Control Foam Panel House, Rainier, WA . . . . . . . . . . . . 8.5

8.3 R-Control Foam Panel House, Anderson Island, WA . . . . . . . . . 8.5 


\section{TABLES}

S.1 Cost Comparison for Various Wall Construction Types ............ . iv

S.2 Foam Panel Manufacturers Perceived Advantages and Disadvantages of Using the Foam Panel Technology in HUD-Code Housing .............v

S.3 HUD-Code Manufacturers Perceived Advantages and Disadvantages of Using the Foam Panel Technology in HUD-Code Housing . . . . . . . . . vi

1.1 Typical Insulation Levels Required by HUD and MAP . . . . . . . 1.1

2.1 EPS Thermal Properties . . . . . . . . . . . . . . . . . 2.2

2.2 Combustion Temperatures for Selected Materials . . . . . . . . . . 2.3

2.3 XEPS Thermal Properties . . . . . . . . . . . . . . . . . 2.4

3.1 Pacific Northwest Panel Manufacturer Warranties . . . . . . . . . . . . 3.4

4.1 Un-Cut Foam Panel Costs . . . . . . . . . . . . . . . . 4.2

4.2 Cost Comparison of Foam Panel and Conventional Site-Built Construction . 4.3

4.3 Cost Comparison for Various Wall Construction Types . . . . . . . . . 4.5

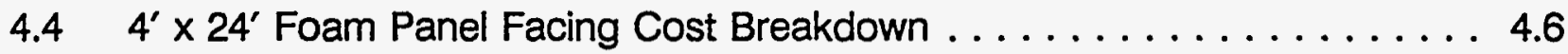

$4.5 \quad 4^{\prime} \times 24^{\prime}$ Foam Panel Cost Breakdown . . . . . . . . . . . . . . . . 4.7

5.1 Selected National Foam Panel Manufacturer Data Base . . . . . . . . . 5.4

6.1 Pacific Northwest Foam Panel Manufacturers . . . . . . . . . . 6.1

7.1 Regional HUD-Code Manufacturers Surveyed $\ldots \ldots \ldots \ldots \ldots \ldots \ldots .1$

8.1 Infiltration Test Results of R-Control Foam Panel Homes . . . . . . . . 8.3 


\subsection{INTRODUCTION}

The Bonneville Power Administration (Bonneville), a federal power marketing agency, is responsible for meeting the electrical needs of the Pacific Northwest including Washington, Oregon, Idaho, and western Montana. To meet the projected increasing electrical demand in the region; Bonneville is trying to reduce future demand through conservation programs. Resources acquired through energy conservation are often less expensive than building additional power generating facilities. A significant area for potential energy savings is the HUD-code manufactured housing market, which represents $45 \%$ of the new electrically heated homes in the region (Onisko 1985).

HUD-code manufactured homes are transported structures that are built on a permanent chassis and are regulated by the U.S. Department of Housing and Urban Development (HUD). The HUD code is pre-emptive so HUD-code housing is not subject to local or state codes (76 FR 13590). To avoid conflicts with the pre-emptive nature of the HUD code, Bonneville developed voluntary energy-efficient manufactured housing programs. The programs have included demonstration projects, the Super Good Cents (SGC) program, and currently the Manufactured Housing Acquisition Program (MAP). All have relied on voluntary participation. MAP is an agreement between Bonneville, the regional electric utilities, and the 19 regional plants to build all electrically heated manufactured homes to stringent energy-efficiency levels. Table 1.1 compares typical HUD-code and MAP insulation levels.

TABLE 1.1. Typical Insulation Levels Required by HUD and MAP

\begin{tabular}{||l|c|c|c|c|c|}
\hline \multirow{2}{*}{} & \multicolumn{5}{|c|}{ TYPICAL INSULATION R-VALUES } \\
\cline { 2 - 6 } & Wall & Roof & Floor & Door & Glazing (Uo) \\
\hline \hline HUD-Code & 11 & 11 & 7 & 5 & 0.80 \\
\hline MAP & 21 & 49 & 33 & 5 & 0.35 \\
\hline \hline Source: Onisko 1992 \\
\hline
\end{tabular}




\subsection{BACKGROUND}

This investigation of structural foam-core panels (foam panels) in manufactured housing was initiated during the SGC program. The SGC program limited allowable glazing area because of the relatively high thermal losses associated with most windows. Due to their superior thermal performance, foam panels appeared to be a viable option to allow increased glazing area without compromising the thermal integrity of the wall. With the inception of the MAP, however, the focus of this study has shifted. MAP permits unlimited glazing area if expensive, super-efficient, vinylframed, argon-gas-filled, low-emissivity coated windows are installed. Although MAP permits unlimited glazing area, a foam panel wall could allow the use of less expensive windows, larger window area, or less insulation and still provide the required thermal performance for the building.

Bonneville contracted with the Pacific Northwest Laboratory (PNL) to investigate the feasibility of using foam panels in HUD-code manufactured housing. This study presents the results from a product and literature search. The potential barriers and benefits to the use of foam panels are determined from a regional survey of the HUDcode manufacturers and foam panel producers.

\subsection{STRUCTURAL FOAM CORE PANELS}

The term "structural foam-core panels" refers to panels in which structural skins, such as sheet metal or panelized wood products, are firmly adhered to both sides of a rigid insulating foam core. The panels utilize a stressed-skin principle where the overall strength of the panel is much greater than the components, thus eliminating the need for structural framing members. The foam panel is structurally analogous to an I-beam, with the facings acting as the flange and the foam as the web as shown in Figure 1.1. Because the panels are structural, they withstand forces and loads imposed on walls, floors and roofs, which, combined with their superior insulating properties, makes them ideal building component materials (Andrews 1992a p. 2-3). Current applications are in site-built residential, low-rise commercial, and cold storage buildings. No past or current applications in HUD-code manufactured housing were identified in this study.

The first formal testing of the structural sandwich panel technology was conducted by the U.S. Forest Products Laboratory. Three homes with an assortment of core configurations and facing materials were built between 1935 and 1947. In 1952, the first foam panel homes in the United States were built in Midland, Michigan. 
The wall panels had 5/16 inch plywood facings bonded to a 1-5/8 inch thick Dow Styrofoam core. It is reported that these homes are still occupied today. The first foam panel manufacturers were established in the 1970s, and the industry continues to expand (Andrews 1992a, p. 6).

The thermal performance of a foam panel is superior to a conventionally framed building component due to its inherent characteristics. Most foams have'a higher Rvalue than standard batt insulation. ${ }^{\mathrm{a}}$ Foam R-values range from R-4 per inch to R-7 per inch, while batt insulation is rated at approximately R-3 per inch (ASHRAE 1989). Evaluating a building components thermal performance based on the individual material R-values is incomplete. For example, a typical frame wall has $2 \times 6$ inch studs placed 16 inches on center as seen in Figure 1.2. Wood members have a lower thermal resistance than insulation, at only R-1.25 per inch (ASHRAE 1989), representing a thermal bridge. A thermal bridge occurs when two adjacent materials have different $R$-values causing the heat to flow through the path of least resistance. In a framed wall using $2 \times 6$ inch studs placed 16 inches on center, $15 \%$ of the heat loss surface is due to the wood studs (ASHRAE 1989). By contrast, the foam panel wall in Figure 1.3 is a continuous insulating surface, thus increasing the overall thermal performance of the wall. Unfortunately, this advantage is often overlooked due to the building industry's insufficient information on the technology (Steve Winter Associates, 1991 p. 1).

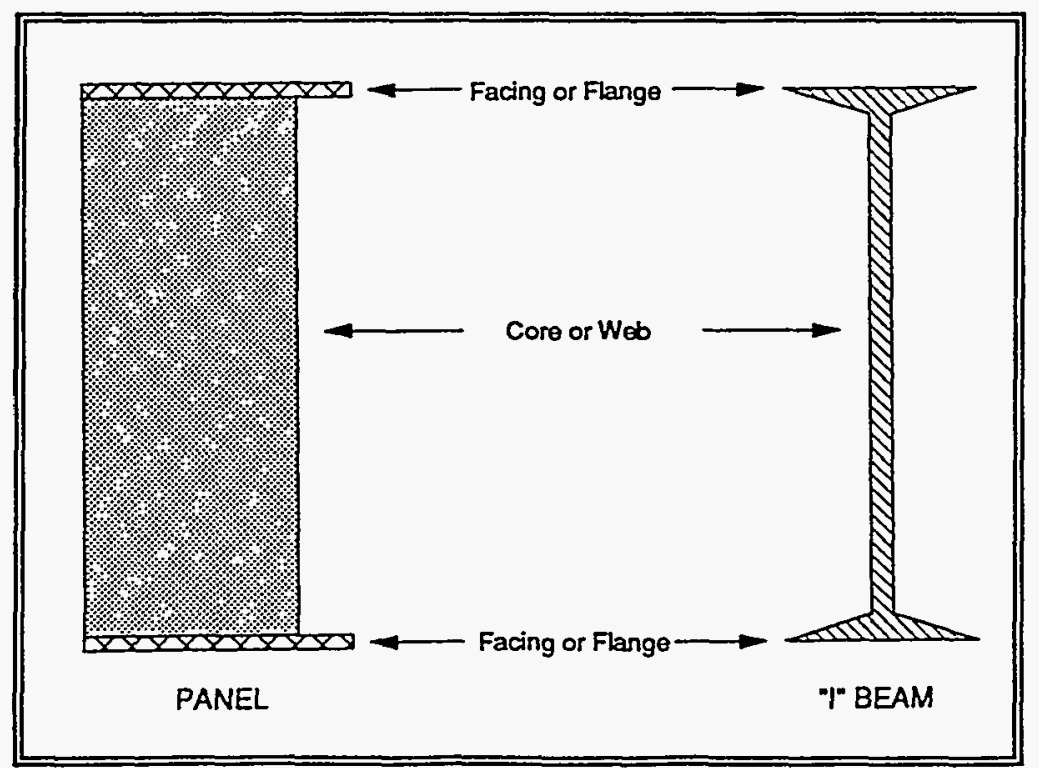

FIGURE 1.1. Analogy of a Foam Panel With an I-Beam Source: Andrews $1992 a$

${ }^{a}$ An R-value is a measure of a material's resistance to heat flow. 


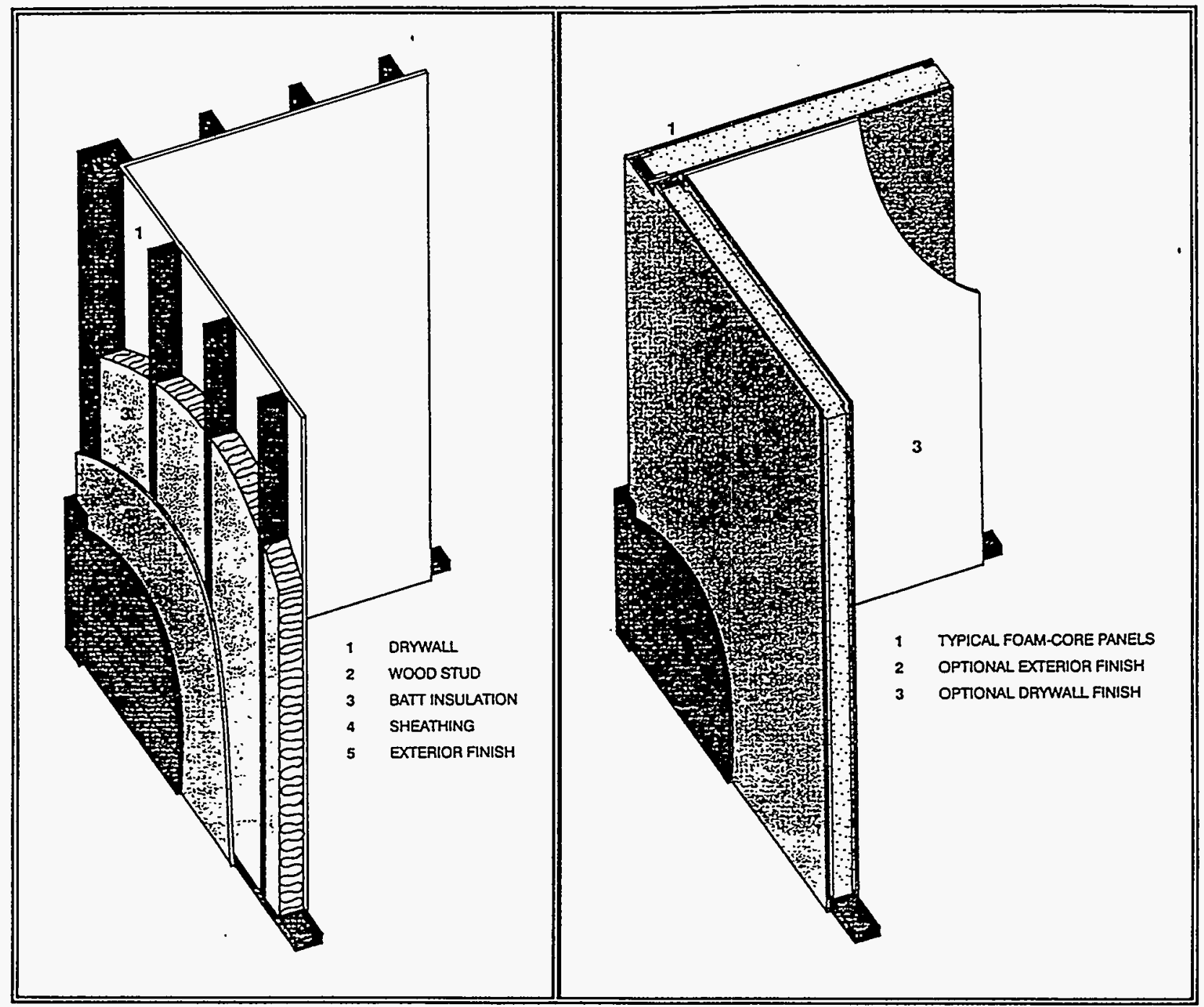

FIGURE 1.2. Frame Wall Construction FIGURE 1.3. Foam Panel Wall Construction Source: Architecture 1991

Source: Architecture 1991

The thermal advantage from a framing member reduction is being overshadowed by the impacts of recent timber price increases and supply uncertainties. The timber industry is balancing environmental and economic policies, causing prices to soar. According to Random Lengths, a weekly lumber market report, prices have been volatile during 1992, and are increasing rapidly in 1993 (see Figure 1.4). The Random Lengths index compares the current ratio of Western sawmill orders to inventory to the 5-year average of the ratio. 
The index was -14.8 for the week ending January 3,1992 , and soared to +60.7 during the week ending January 8, 1993. The demand has far exceeded the supply causing variable price swings. A dealer in the South who started using steel studs issued this warning: "These wild price swings will force contractors to start using products that they can plan to use and know what their cost will be" (Random Lengths 1993). Most foam panel manufacturers use panelized wood facings, such as oriented strand board (OSB) and plywood, which are still subject to price fluctuations. However, these products are manufactured using non-old growth trees so the supply fluctuation impacts are less severe.

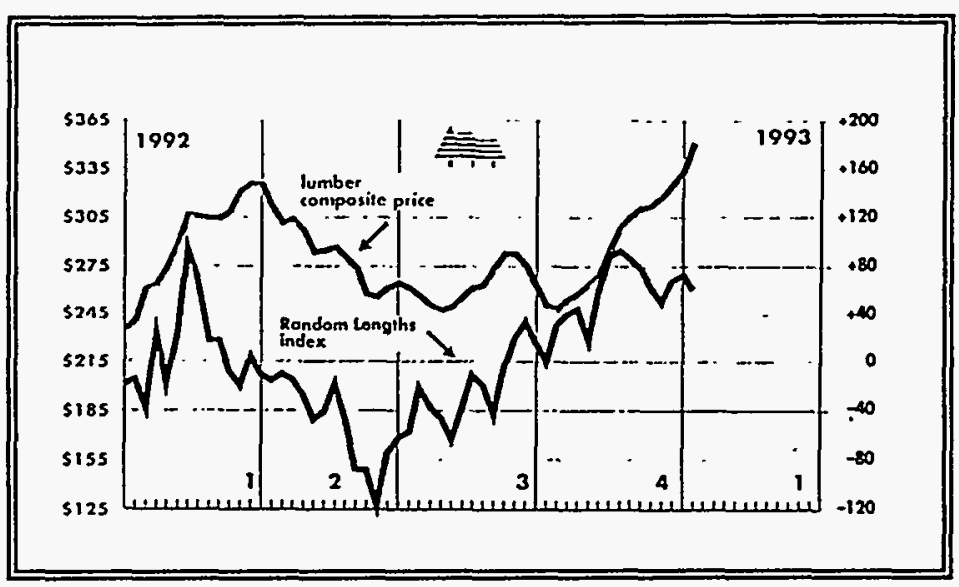

FIGURE 1.4. 1992 Framing Lumber Market Price and Index Source: Random Lengths 1993 


\subsection{FOAM PANEL MATERIALS AND CONSTRUCTION}

A foam panel consists of an insulating foam core sandwiched between two structural facing materials. . Typical foam types used are expanded polystyrene, extruded polystyrene, urethane, and polyisocyanurate. The manufacturing process, 'thermal properties, and combustibility of each foam type will be discussed. The two general categories of structural facing materials are sheet metal and panelized wood. For residential construction, panelized wood is predominant, specifically OSB.

Foam panel construction is distinct from conventional frame construction in many aspects. The panels must be lifted in place and pieced together using panel connection methods, which vary by manufacturer. Since the foam panel is an integral building component, wiring and plumbing procedures require additional planning.

\subsection{EPS FOAM}

Expanded polystyrene (EPS) is a molded bead-like, closed-cell foam (Andrews 1992a, p. 20). According to Western Insulfoam, one of the West's largest EPS producers, EPS contains no chlorofluorocarbons (CFCs) or formaldehyde. It is chemically inert, will not support any bacteria or fungus growth, and does not provide nutritive value to rodents or insects.

\subsubsection{EPS Manufacturing Process}

On May 6, 1992, PNL had the opportunity to tour the Western Insulfoam manufacturing plant in Kent, Washington; a typical EPS manufacturing plant. According to the Western Insulfoam representative, the raw material used to manufacture EPS is virgin plastic beads with approximately $6 \%$ pentane. The pentane is used as a blowing agent for expansion. Eventually the virgin plastic will be replaced with a recycled product; it is unknown how this will affect the EPS manufacturing process and $R$ value. Currently, the foam is manufactured in two steps, pre-expansion and molding.

During the pre-expansion process, the beads are placed in a hopper where steam is injected at about $220 \mathrm{~F}$. The steam releases approximately one-half of the impregnated pentane, causing the beads to expand. The pre-expansion process is analogous to a popcorn popper in that the beads are simply "puffed-up." 
Foam density is controlled by the steam exposure time because it is directly proportional to bead expansion. For one-pound-density foam, the density most commonly used in the foam panel industry, a one-day aging period is necessary to allow air to fill the voids. A five-day aging period is required for two-pound-density foam; because of the increase in production time, two-pound-density foam is more expensive to manufacture resulting in a higher purchase price.

After the initial aging period, the beads are gravity-fed into a rectangular mold. A vacuum from the bottom of the mold extracts steam from each side of the mold. The vacuum is eliminated, while the steam is still injected, until a uniformly distributed pressure of eight to ten pounds per square inch is achieved. This pressuretemperature combination releases the residual pentane from the beads causing them to fuse. The molding process is complete once the mold wall pressures are balanced. The foam blocks are aged for three to five days at approximately $140 \mathrm{~F}$ to allow for expansion and contraction. A hot wire is used to cut the blocks to the required dimensions and are then ready for transportation.

The most common EPS panel fabrication process glue-bonds the facings to the foam block. A water-based structural-grade adhesive is applied to both sides of the foam, which is then sandwiched between the facing material. A stack of panels is placed under continuous pressure for approximately one hour, then an additional 24hour aging period is required to cure the adhesive (Winter 1992a p. 21).

\subsubsection{EPS Thermal Properties}

EPS is stable and is not subject to thermal drift, which is the gradual loss of Rvalue caused by air permeating the foam cells. The thermal resistance of EPS is a function of density and temperature. Foam that is aged to a greater density, has additional air pockets which increase its thermal resistance. EPS also has a higher Rvalue in colder temperatures. See Table 2.1 for EPS thermal properties.

TABLE 2.1. EPS Thermal Properties

\begin{tabular}{|l|l|l|l|l|}
\hline Density $\left[\mathrm{lb} / \mathrm{ft}^{3}\right]$ & 1.0 & 1.0 & 2.0 & 2.0 \\
\hline Temperature & $40 \mathrm{~F}$ & $75 \mathrm{~F}$ & $40 \mathrm{~F}$ & $75 \mathrm{~F}$ \\
\hline R-Value / inch & 4.0 & 3.6 & 4.6 & 4.2 \\
\hline \hline
\end{tabular}


EPS can easily withstand temperature cycling in cold environments. The maximum use temperature is $167 \mathrm{~F}$ for continuous exposure, and $180 \mathrm{~F}$ for intermittent exposure. When exposed to temperatures in the $200 \mathrm{~F}$ to $300 \mathrm{~F}$ range, the foam will melt (Andrews 1992a, p. 24).

\subsubsection{EPS Combustibility}

The flash and self-ignition temperatures for EPS are well above those of paper and wood, as shown in Table 2.2. Flash ignition is the temperature at which a material will give off a vapor and, when mixed with air, is ignitable by an external source. At the self-ignition temperature, the material will spontaneously smoke or flame without an external flame source. Because EPS is a polymer of carbon and hydrogen, carbon monoxide and other toxic gases are released upon burning. However, similar gases are released from wood and most household products and furnishings (Andrews 1992a, p. 24).

TABLE 2.2. Combustion Temperatures for Selected Materials

\begin{tabular}{|l|c|c|}
\hline Material & Flash Ignition Temp. ( F) & Self-Ignition Temp. ( F) \\
\hline \hline EPS & $650-725$ & $875-925$ \\
\hline Paper & 445 & 445 \\
\hline Pine & $406-507$ & 500 \\
\hline \hline \multicolumn{2}{|l|}{ Source: Andrews 1992a, p. 25 } \\
\hline
\end{tabular}

\subsection{XEPS FOAM}

Extruded polystyrene (XEPS) is a polystyrene foam extruded, rather then expanded, into panels creating a closed-cell rigid foam. Extrusion is a manufacturing process where the material is pushed through a pre-formed die. XEPS has greater density and compressive strength, and better thermal properties than EPS; however, it is more expensive. Extruded polystyrene has only been used in foam panel applications since 1989 (Andrews 1992a, p. 29). 


\subsubsection{XEPS Manufacturing Process}

XEPS begins as a solid granule that is fed into an extruder. The granules are melted and a non-CFC blowing agent is injected into the mixture to make it foamable. It is then forced through a die where the foam is shaped to the desired dimensions. Panel fabrication is similar to that described for EPS (Andrews 1992a, p. 29).

\subsubsection{XEPS Thermal Properties}

Once the XEPS has been extruded, the thermal resistance is approximately $R$ 8.0 per inch. However, the blowing agent rapidly outgasses during the first three months, causing the R-value to decrease. The "aged" R-value is approximately R-5.0 per inch. Unlike EPS, the R-value is unaffected by the density. The average density is $1.5 \mathrm{lbs} / \mathrm{fl}^{3}$. As with EPS, thermal performance increases with decreasing temperatures as shown in Table 2.3. All other thermal properties are similar to EPS (Andrews 1992a, p. 29).

TABLE 2.3. XEPS Thermal Properties

\begin{tabular}{|l|l|l|}
\hline AMBIENT TEMPERATURE & $40 \mathrm{~F}$ & $75 \mathrm{~F}$ \\
\hline AGED R-VALUE & 5.4 & 5.0 \\
\hline \hline Source: Andrews 1992a, p. 29 \\
\hline
\end{tabular}

\subsubsection{XEPS Combustibility}

The combustibility characteristics of XEPS are similar to those of EPS (Andrews 1992a, p. 29). 


\subsection{URETHANE \& POLYISOCYANURATE FOAM}

Urethane and polyisocyanurate are closed-cell plastic foams where the cells contain Freon, a low-conductivity CFC gas. Since polyisocyanurate and urethane are chemically similar, their properties and characteristics are used interchangeably in this report (Andrews 1992a, p. 20). These foams have one of the highest R-values of all building materials (Andrews 1992a, p. 31). Winter Panel, a manufacturer of urethane foam panels, expects to convert to a less destructive hydro-CFC foaming agent within two years. The agent is still ozone depleting, but to a lesser extent. Under international treaty, all ozone depleting substances are being phased out of production due to their suspected effect on the Earth's stratospheric ozone layer (Energy Design Update 1993 p. 12).

\subsubsection{Urethane \& Polyisocyanurate Manufacturing Process}

The urethane and polyisocyanurate foam manufacturing process is complex. The chemicals must be properly formulated, properly mixed, and sufficiently cured under continuous pressure in a controlled temperature range. This results in higher cost. The average foam density is $2.0 \mathrm{lbs} / \mathrm{ft}^{3}$ (Andrews 1992a p. 31). Urethane and polyisocyanurate panels are either foamed-in-place or glue-bonded. The foamed-inplace process involves injecting the foam between the panel facings which are held apart by spacers. The liquid foam expands to fill the cavity and will adhere to the facings, resulting in a strong bond. This panel fabrication process requires the foam to be manufactured on-site. Glue-bonded panel fabrication is identical to the EPS process where an adhesive is applied to a precut foam block, which is then pressed between the facing materials. The foam can be either formed on-site or bought from a manufacturer. The foamed-in-place procedure is predominant (Andrews 1992a, p. 32).

\subsubsection{Urethane \& Polyisocyanurate Thermal Properties}

Initially, the thermal resistance of urethane and polyisocyanurate is approximately R-7.0 per inch. However, these foams suffer from "thermal drift" which, over time, causes a decrease in R-value. Thermal drift is caused by air permeating into the foam cells. This dilutes the Freon gas, which is responsible for the high thermal resistance, causing a drop in the R-value. In combination with the Freon gas dilution there is a slow "outgassing" of Freon, which also decreases the R-value. Unfortunately, limited data exist concerning the magnitude of the R-value reduction and the duration of the aging period (Andrews 1992a p. 33). 


\subsubsection{Urethane \& Polyisocyanurate Combustibility}

The self-ignition temperature, the temperature at which the material will spontaneously smoke or flame, is between $800 \mathrm{~F}$ to $850 \mathrm{~F}$. Below that temperature range the foam will char or burn rather than melt like EPS and XEPS (Andrews 1992, p. 35). Urethane and polyisocyanurate do not contain any formaldehyde-related chemicals. However in a fire, carbon monoxide and trace amounts of hydrogen cyanide are released, both very deadly gases. (Andrews 1992b).

\subsection{FACING MATERIALS}

Two general categories of facing materials are used for foam panels: sheet metal and panelized wood. Sheet metal facings vary in gage thickness and are primarily used in cold storage and some commercial building applications. Panelized wood facings are predominant in residential and light commercial construction. Common wood facings include plywood, waferboard, and OSB. OSB is prevalent because it is available in large continuous sheets, up to 8 feet wide by 28 feet long (Andrews 1992a, p. 39).

OSB, developed in the early 1980s, is an advancement of waferboard. It is an engineered product made exclusively by processing small-diameter, fast-growing trees into strands. It is a mat-formed panel product where the wood strands are layered and pressed together. The surface layer strands are aligned lengthwise and the inner layers are random or cross aligned giving it greater dimensional stability than waferboard, whose strands are entirely random. The strands and layers are bonded together under heat and pressure with a waterproof resin (Structural Board Association 1992).

The resins, in combination with the oriented strands, give OSB dimensional stability and moisture resistance. OSB and waferboard permeability, the rate at which moisture passes through a material, compares favorably with plywood. The thermal resistance of OSB is R-1.32 per inch and is similar to other wood-based products such as plywood (Structural Board Association 1992).

Louisiana-Pacific has recently developed a structural gypsum wallboard called FiberBond, which could replace the interior foam panel facing and gypsum wallboard, reducing material and manufacturing costs. FiberBond panels consist of gypsum, perlite, and cellulose fiber made from recycled newspaper. It is two to three times more rigid than conventional gypsum wallboard. FiberBond panels can provide the 
same fire resistance classification as the equivalent thickness of gypsum, providing all other installation requirements are met (Louisiana-Pacific Corporation 1993). Since this product is new to the building materials market, adequate testing has not been completed by the foam panel manufacturers.

\subsection{CONSTRUCTION TECHNIQUES}

Standardized construction techniques will vary depending on the foam panel manufacturer and builder. The majority of foam panel manufacturers utilize the construction techniques discussed in this section.

\subsubsection{Panel to Panel Connection Methods}

Panel connection techniques vary between foam panel manufacturers. However, there are some consistent methods within the industry. The following are examples of the various connection methods.

Double Spline - Figure 2.1 is an example of the double-spline connection. This eliminates thermal bridging at panel-to-panel connections; however, wood framing members are necessary at building component connections, window and door openings, and for structural support in some applications. Two thin splines, $1 / 2$ to $3 / 4$ inch thick by 3 to 4 inches wide and made of OSB or plywood, fit in factory precut notches in each panel edge (Andrews 1992a, $p$. 48).

Framing Member Spline - Another method of foam panel connection is to use dimensional two-by framing members the same width as the foam core. The foam core is routed to accept half of the framing member as shown in Figure 2.2. The use of a framing member adds some strength. For example, a framing member may be required for the roof panel connection due to the design load and span. However, framing members are not required for most applications. One disadvantage when using framing members is that they create a thermal bridge, thus reducing the insulation value of the building component. These connections could also be a source of air infiltration if not properly sealed. 
Thermally Broken Spline - Figure 2.3 shows a thermally broken spline. This method eliminates thermal bridging at the connection; however, it must be premanufactured increasing the cost of the foam panel.

Cam-Lock - A mechanical joining system using cam-locks (Figure 2.4) is used by some manufacturers. This system does not create a thermal break and allows for quick and easy panel attachment. It is assumed that the cost of the cam-lock system would increase the cost of the foam panel.

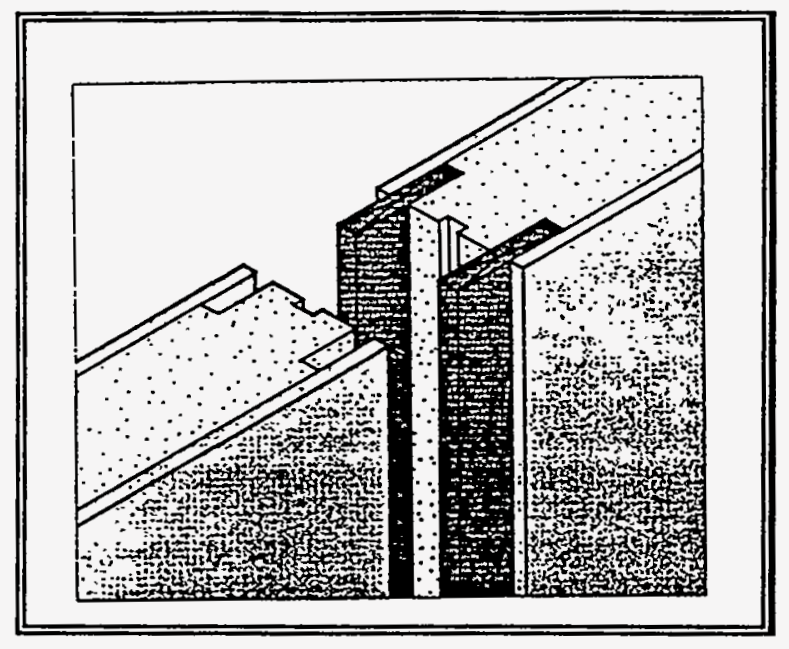

FIGURE 2.1. Double Spline Panel Connection

Source: Architecture 1991

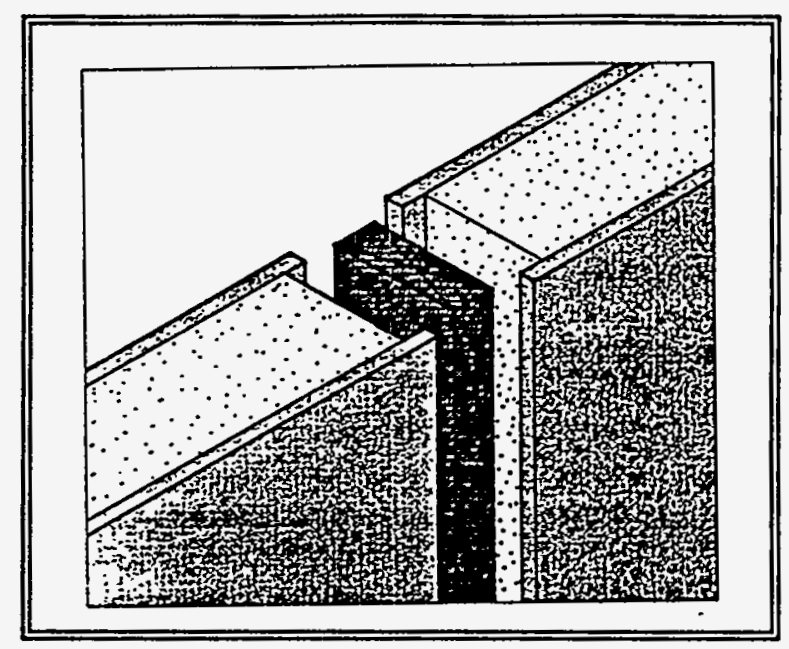

FIGURE 2.2. Framing Member Spline Panel Connection Source: Architecture 1991 


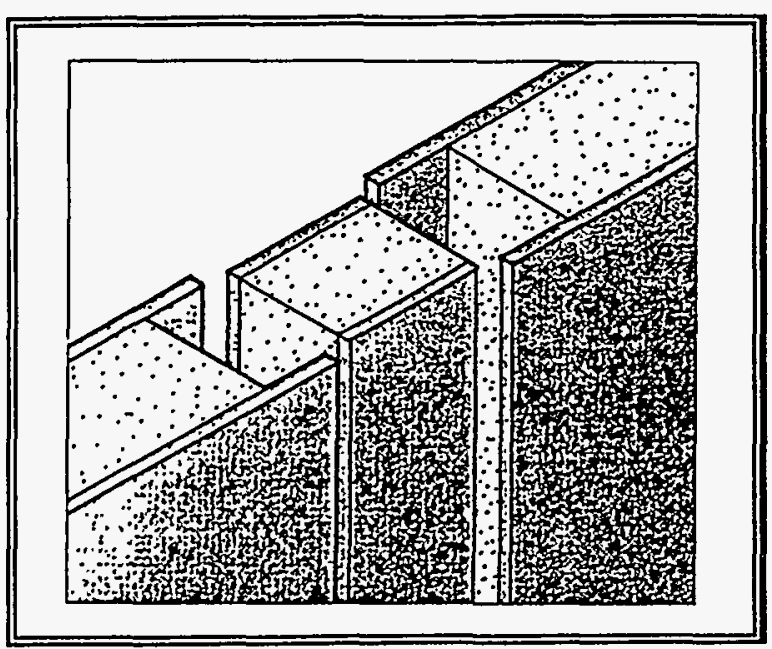

FIGURE 2.3. Thermally Broken Spline Panel Connection Source: Architecture 1991

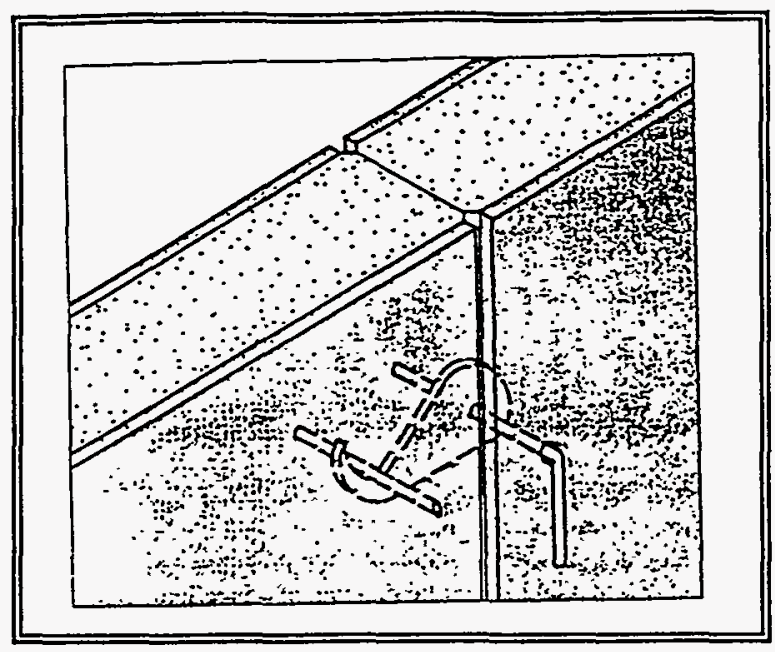

FIGURE 2.4. Cam-Lock Panel Connection Source: Architecture 1991 


\subsubsection{Construction Details}

Typical foam panel construction details are shown in the following figures:

Figure 2.5, ridge beam; Figure 2.6, vaulted roof to wall connection; Figure 2.7, wall corner; and Figure 2.8, wall to floor connection.

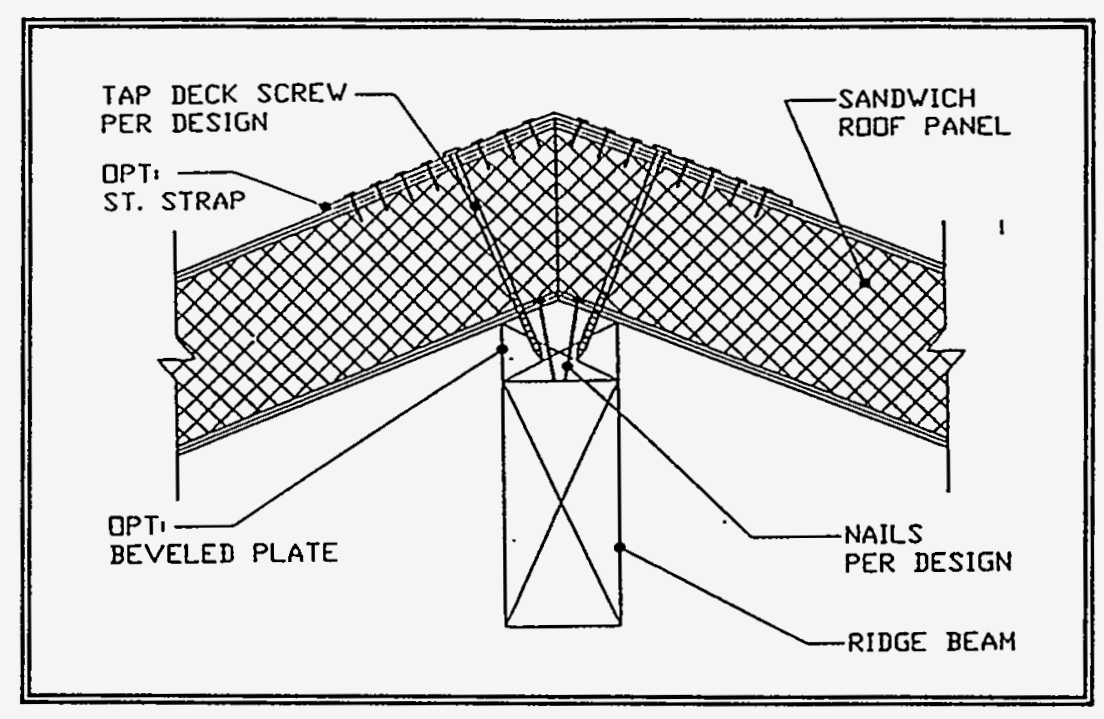

FIGURE 2.5. Foam Panel Ridge Construction Detail Source: URSA Structural Systems

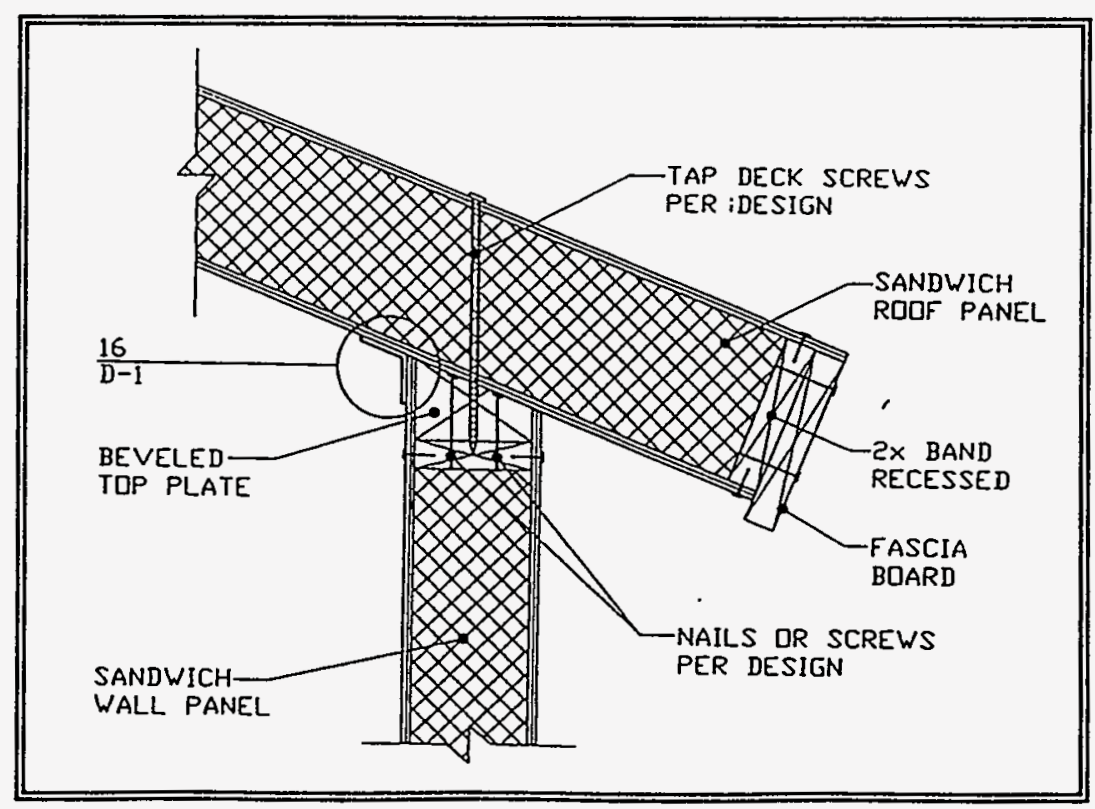

FIGURE 2.6. Foam Panel Roof to Wall Construction Detail Source: URSA Structural Systems 


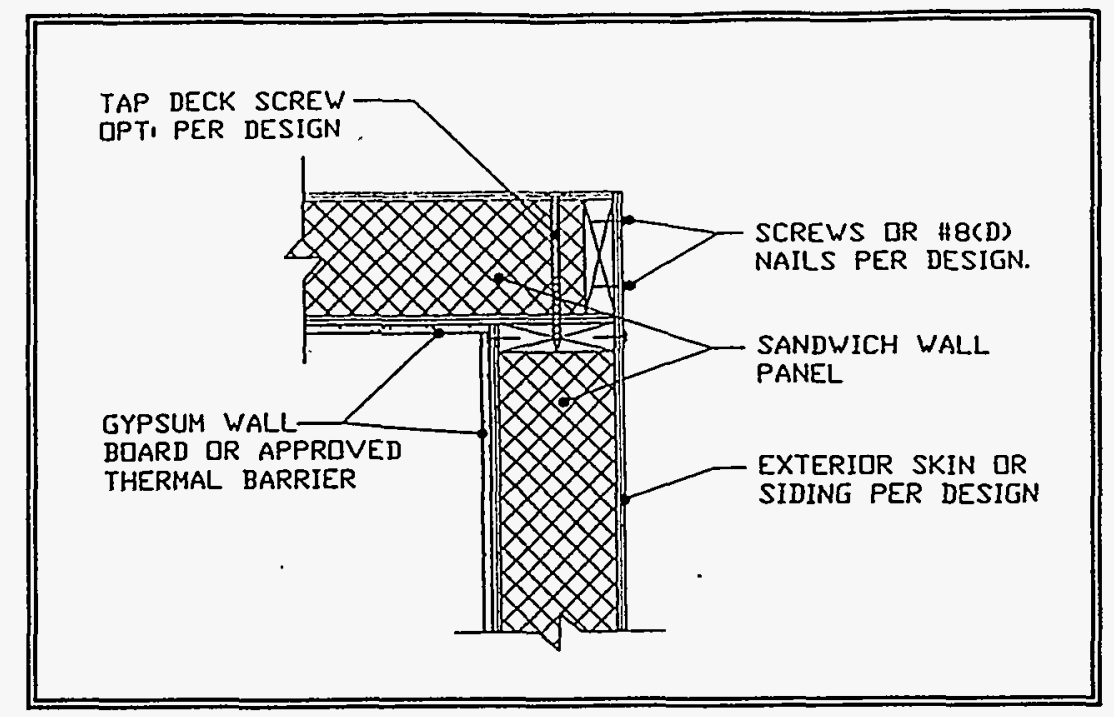

FIGURE 2.7. Foam Panel Wall Corner Construction Detail Source: URSA Structural Systems

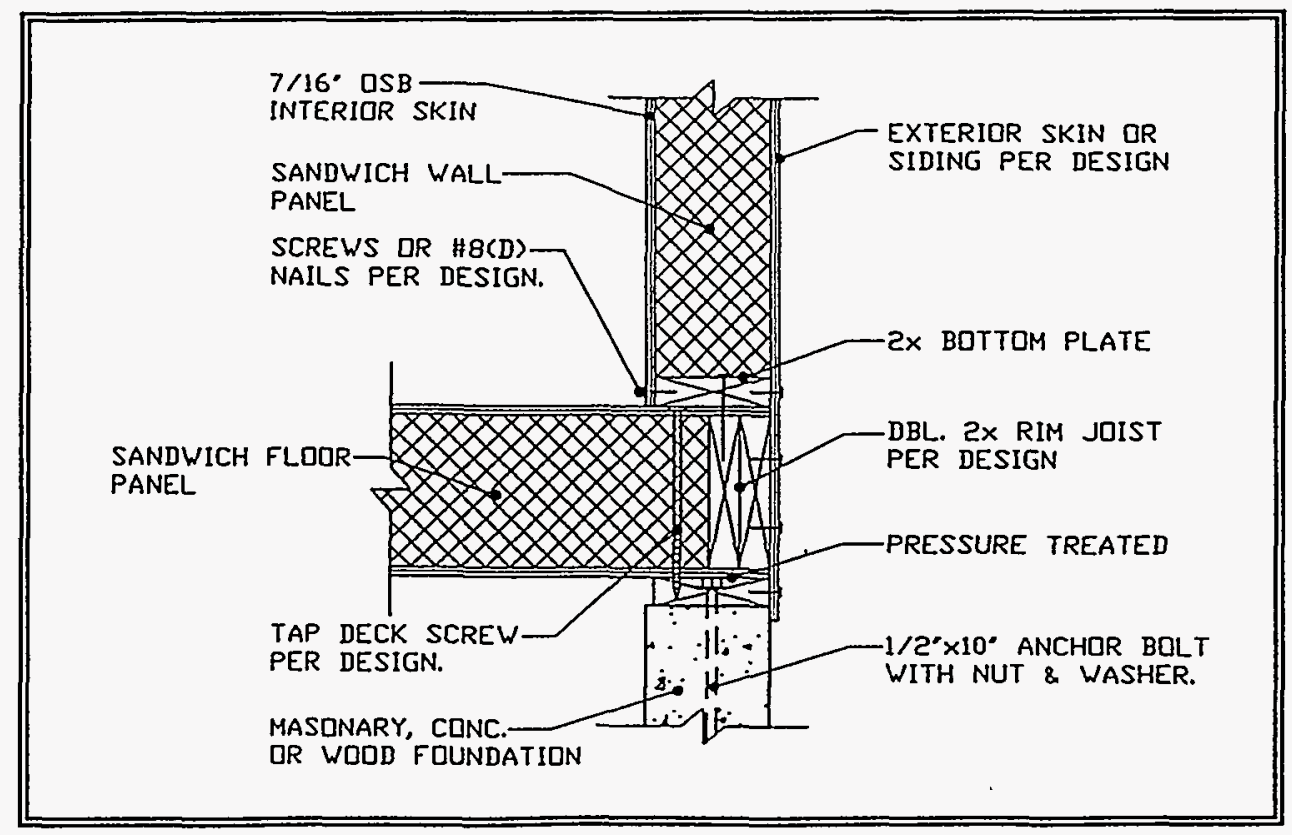

FIGURE 2.8. Foam Panel Wall to Floor Construction Detail Source: URSA Structural Systems 


\subsubsection{Wiring}

For each foam panel section, most manufacturers will pre-rout wiring chases into the foam core. A common chase configuration consists of two horizontal chases, one each at the receptacle and switch height, and one vertical chase down the center (see Figure 2.9). Other manufacturers will route electrical chases according to the customer's design specifications. The wiring can be installed by either using a pullwire once the panels are in place, or fed through as each panel is erected, depending on the electrician's preference. The wiring is coated with Romex, an insulating coating. The electrical box can be cut by the foam panel manufacturer or the builder and installed according to standard procedures. See Figure 2.10 for an electrical box detail. Although this wiring technique seems labor intensive, there is an associated learning curve.

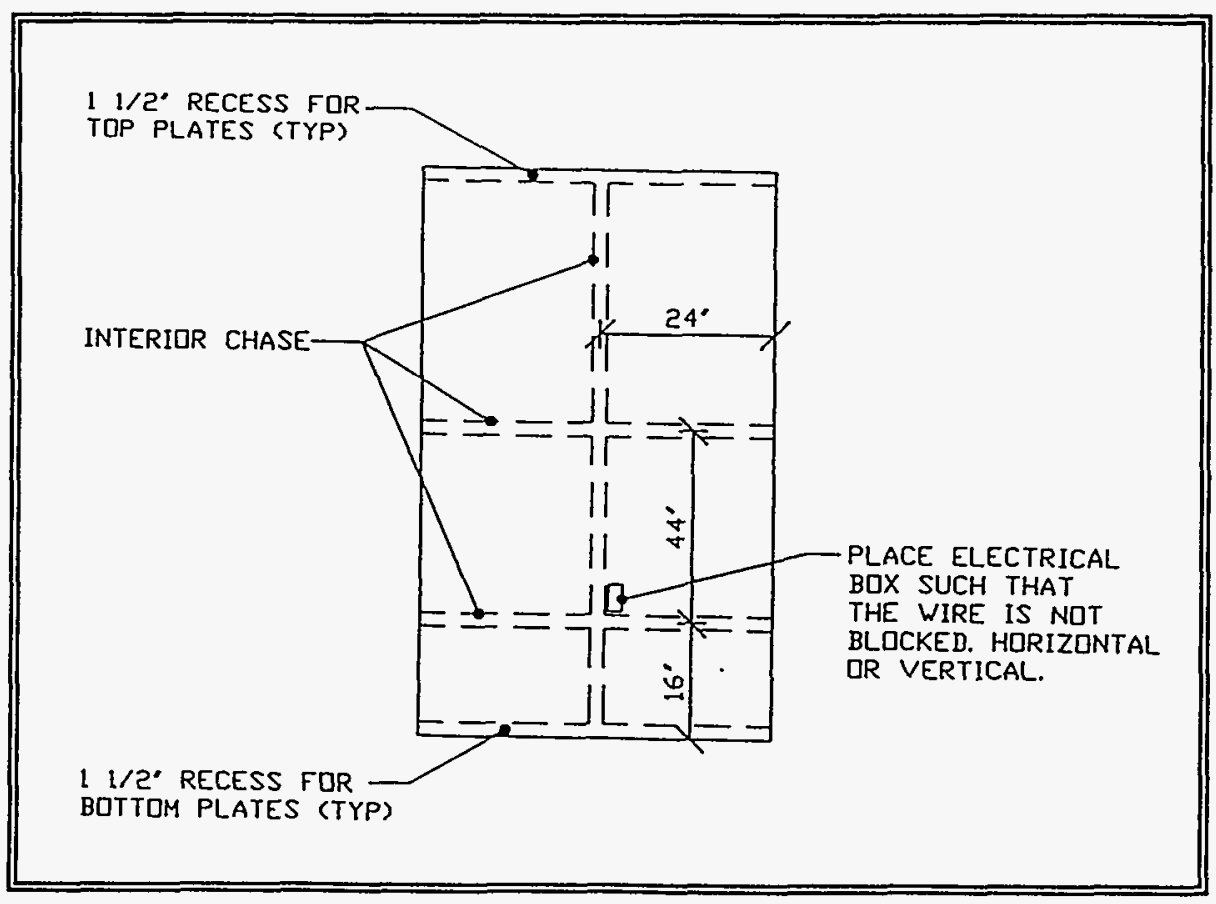

FIGURE 2.9. Typical Location of Foam Panel Electrical Chases Source: URSA Structural Systems 


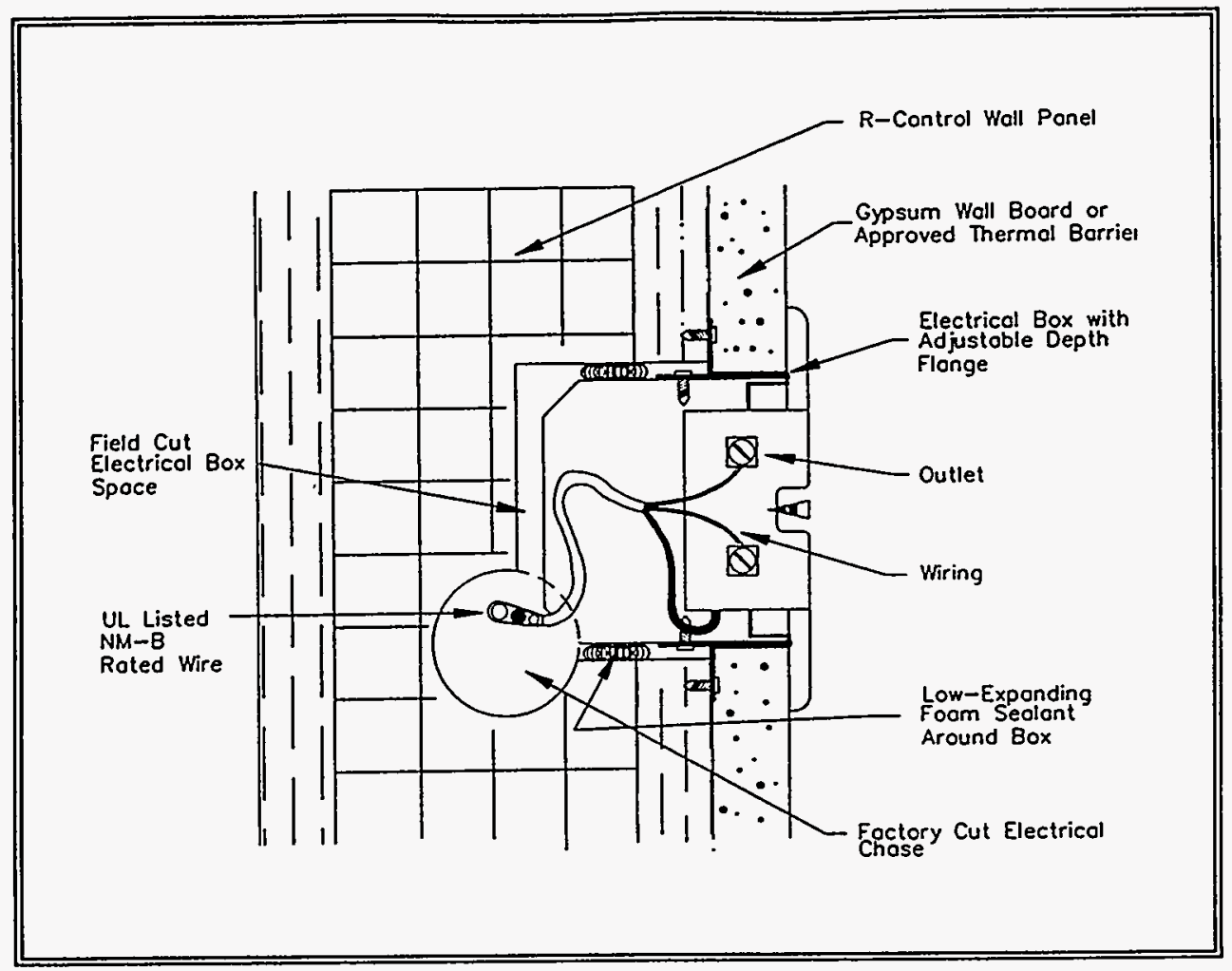

FIGURE 2.10. Foam Panel Electrical Box Detail Source: AFM R-Control 


\subsubsection{Plumbing}

According to various foam panel manufacturers, whenever possible, plumbing supplies and vents should be run in interior walls. If that is not possible, a plumbing chase could be built as seen in Figure 2.11. Another option is to rout a section out of the foam panel to accept the plumbing lines, but this reduces the thermal performance and could compromise the structural integrity (Andrews 1988). The acceptance criteria for an International Conference of Building Officials (ICBO) states that plumbing and waste lines may penetrate wall panels at a right angle, but prohibits placement within the core (International Conference of Building Officials 1977, p. 3).

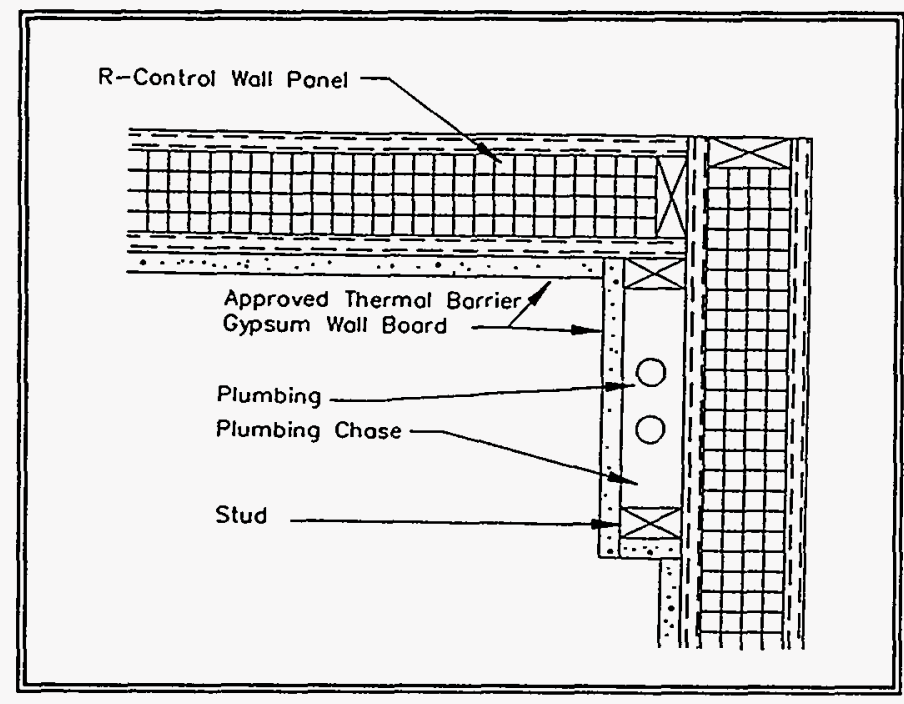

FIGURE 2.11. Foam Panel Plumbing Chase Detail Source: AFM R-Control 


\subsection{PERFORMANCE ISSUES}

Because the foam panel building system deviates from conventional wood frame construction, performance issues are raised. The foam panel structural integrity is often questioned since structural framing members are not required in most applications. Foam panels are laminated making delamination, which is managed. through quality control programs, a valid concern. The insulation material used is a foam product bringing about concerns of insect and rodent infestation and fire safety. Although these performance issues are valid concerns for most construction materials and methods, they represent barriers to the foam panel industry.

\subsection{STRUCTURAL INTEGRITY}

Foam panel houses provide excellent structural stability because foam panels are not prone to warping or racking like dimensional lumber (Hufnagel 1989). A panel wall can withstand tremendous wind loads. According to URSA Structural Systems, a regional foam panel manufacturer, at wind speeds of 120 miles per hour, a standard wall panel can carry a 2,000-pound-per-linear-foot vertical load, exceeding the 1991 Uniform Building Code requirements. URSA's standard wall panel is 10 feet high, consists of a 5-1/2. inch EPS foam core and, $1 / 2$ inch interior and 5/8 inch exterior OSB facings.

The ultimate structural integrity test of a building would be to withstand hurricane force winds. Hurricane Andrew that ripped through the Southeastern U.S. in August of 1992 provided an opportunity for such a test. It was learned by Korwall Industries, Inc. of Arlington, Texas, that a home in Franklin, Louisiana, constructed of its EPS foam panels survived Hurricane Andrew's 160-mph winds. A porch attached to the home sustained slight damage, however no cracks were found in the structure itself. During the storm, the house did not creak, groan, or move when the winds bombarded it for five hours. Several other homes in Louisiana constructed of Korwall foam panels endured the storm as well (Building Systems Builder 1993). 


\subsection{QUALITY CONTROL}

To obtain a model building code listing for foam panels, the manufacturer must contract with an independent laboratory to perform structural and fire tests to confirm compliance with the recognized standards. The results are sent to the appropriate model code organization (International Conference of Building Officials (ICBO), Building Officials and Code Administrators (BOCA), and the Southern Building Code Congress International (SBCCI)) to obtain the code listing. In 1991, there was a 10\% to $15 \%$ increase of National Evaluation Service applications, an organization which evaluates building materials for code approval, indicating an increase in the industry's quality control. To maintain a model code listing, the foam panel manufacturers are required by the model code organization to maintain a quality control program and a follow-up inspection. The quality control program must be established with a recognized quality assurance agency (Blair 1991, p. 12). A typical quality control program consists of a thorough review of the manufacturers's quality control records, production process monitoring, and random sampling and testing for the appropriate code compliance. Product certification not only protects the manufacturer but provides the customer with documentation, which should ease any concerns regarding delamination and structural integrity (Blair 1992, p. 3).

Unfortunately, there is not a standardized test method specific to foam panels. The testing procedure is dependent upon the judgement of the code officials and model code agencies. An American Society for Testing and Materials (ASTM) task group has been formed to develop specific foam panel test methods that should provide consistent code approval (Blair 1992, p. 3).

\subsection{INSECTS AND RODENTS}

Insects and rodents can wreck havoc on any building material. Insects can cause a loss in structural and thermal integrity (Chappell 1990, p. 11). While wood is a dietary staple for carpenter ants, they also eat all types of foam. The foam does not provide any nutritive value, but it does make a comfortable nesting environment (Andrews 1992a, p. 26). As a whole, insect damage is more widespread in areas that already tend to have infestation problems (Andrews 1992a, p. 27). 
Rodents are less of a threat than insects since they represent a smaller population. Foam manufacturers, such as Western Insulfoam, treat the foam with a borax-based insect repellant integrated into the foam during molding. Some manufacturers take it one step further by spraying the facings after lamination. Western Insulfoam claims their pest repellant, Tim-Bor, is effective over the lifetime of the building.

\subsection{FIRE SAFETY}

The BOCA code requires that any foam shall not exceed a flame spread rating of 75 and a smoke-developed rating of 450 using the ASTM E-84 test procedure. The ASTM E-84 test procedure requires that a 24-foot-long material sample be placed along the ceiling of a small-diameter firebrick tunnel. The sample is fired from below at one end of the tunnel. The rate of smoke and flame spread down the sample is measured and compared to that for burning oak, which has an arbitrary value of 100 . Most foam panels have flame spread and smoke development ratings of 23 and 300 respectively, which are below the maximum ratings of 75 and 450 (Andrews 1992a, $p$. 69). Any holes cut through a foam panel building component must be encased with wood framing as a fire stop because the foam will burn or melt at high temperatures and release toxic fumes (Andrews 1992a, p. 67). Most building codes require a 15minute fire-rated material, typically gypsum, on the interior side of the wall.

\subsection{MANUFACTURER WARRANTIES}

Most panel manufacturers offer warranties against structural defects and delamination. Table 3.1 lists warranties offered by some of the Pacific Northwest panel manufacturers. Material warranty which is a critical factor for HUD-code manufacturers. 
Table 3.1. Pacific Northwest Panel Manufacturer Warranties

\begin{tabular}{||l|l|}
\hline Panel Manufacturer & Warranty Condition \\
\hline \hline APC International & $\begin{array}{l}1 \text { year construction; limited lifetime for } \\
\text { life of the structure; individual materials } \\
\text { warranty; non-transferrable. }\end{array}$ \\
\hline Panels International, Inc. & Lifetime; non-transferrable. \\
\hline $\begin{array}{l}\text { Premier Building Systems } \\
\text { (R-Control Manufacturer) }\end{array}$ & $\begin{array}{l}\text { Lifetime against delamination; } \\
\text { transferable. }\end{array}$ \\
\hline US Building Panels, Inc. & $\begin{array}{l}90 \text { days against delamination; lifetime if } \\
\text { representative on-site during } \\
\text { construction; non-transferrable. }\end{array}$ \\
\hline
\end{tabular}




\section{$4.0 \cos T$}

Because this study did not reveal any prior or current use of foam panels in HUD-code housing, cost data specific to this industry were unavailable. Material and labor costs were available for site-built construction; however, they are not directly comparable to the HUD-code industry, which allows high-volume, year-round production. A foam panel plant's production rate, inventory, and backlog are significant factors in determining the cost.

\subsection{FOAM PANEL MANUFACTURER COST}

Factors that affect foam panel costs are foam type, foam thickness, facing materials, volume ordered, and the foam panel plant's production capacity. Table 4.1 lists selected manufacturer's list prices per square foot of panel for a typical un-cut foam panel that can be used for the roof, wall, or floor. A typical foam panel measures 4 to 24 feet wide by 8 feet high, has OSB facings, vertical and horizontal electrical chases, and the foam at the panel edge is routed to accept spline connections and dimensional framing members. With the exception of Manufacturer $E$, it is assumed that the un-cut foam panel costs in Table 4.1 are conservative and reflect a fixed production capacity. The quantity ordered is a significant factor when the foam panel manufacturer determines the cost. As seen in Table 4.1, when Manufacturer E's customer's annual order increases from $6,000 \mathrm{ft}^{2}$ to $100,000 \mathrm{ft}^{2}$, there is an approximate $10 \%$ EPS and $20 \%$ urethane foam panel cost reduction per square foot.

Pre-cut foam panels are more labor intensive. A typical "pre-cut package" offered by foam panel manufacturers includes the un-cut options, customer's building design adapted to accommodate panel construction, panels cut per revised plan including window and door openings, and each panel numbered for construction. Pre-cut foam panel costs range from $\$ 8$ to $\$ 13$ per square foot of panel. When the panel manufacturer installs the wall, roof, and floor foam panels on a builder's foundation, costs range from $\$ 16$ to $\$ 22$ per square foot of floor area (Blair 1991, $p$. 53). 
TABLE 4.1. Un-Cut Foam Panel Costs

\begin{tabular}{|c|c|c|c||}
\hline Panel Manufacturer & Foam Type & $\begin{array}{c}\text { Foam Width } \\
\text { (inches) }\end{array}$ & $\begin{array}{c}\text { Cost } \\
\left(\$ / \mathrm{ft}^{2}\right)\end{array}$ \\
\hline \hline A & EPS & $3-5 / 8$ & 2.70 \\
& & $5-5 / 8$ & 2.99 \\
\hline B & EPS & $3-9 / 16$ & 1.91 \\
$\left(0-5,000 \mathrm{ft}^{2}\right.$ volume $)$ & Styrofoam & $3-5 / 8$ & 2.37 \\
& Urethane & $3-9 / 16$ & 2.65 \\
\hline C & EPS & $3-5 / 8$ & 2.22 \\
& & $5-5 / 8$ & 2.68 \\
\hline D & EPS & $3-9 / 16$ & 2.29 \\
& & $5-9 / 16$ & 2.62 \\
\hline E & EPS & $3-1 / 2$ & 2.01 \\
$\left(0-6,000 \mathrm{ft}^{2}\right.$ & & $5-1 / 2$ & 2.25 \\
annual volume $)$ & Urethane & $3-1 / 2$ & 2.94 \\
& & $4-1 / 2$ & 3.29 \\
\hline E & EPS & $3-1 / 2$ & 1.80 \\
volume $)$ & & $5-1 / 2$ & 2.05 \\
& Urethane & $3-1 / 2$ & 2.30 \\
$\left(100,000-200,000 \mathrm{ft}^{2}\right.$ annual & & $4-1 / 2$ & 2.65 \\
\hline
\end{tabular}

\subsection{FOAM PANEL COST COMPARISONS}

A recent cost analysis conducted by Panels International Incorporated, a Northwest manufacturer of EPS foam panels, compared its roof, wall, and floor panel systems to equivalent conventionally framed systems. This information was compiled from builder material cost sheets, based on historical data, and the Residential Cost Handbook (1993). The general contractor's overhead and profit, and installation costs were included. A cost index for the Seattle, Washington area was used. Table 4.2 summarizes the results. For each building component, the foam panel construction was less expensive per square foot. The cost savings range from $17 \%$ for the floor and $18 \%$ for the roof, to $27 \%$ for the wall. The foam panel components also had a higher estimated R-value than the conventionally framed counterpart. From this cost comparison, foam panels are cost competitive with site-built construction and appear to be the cost-effective choice for the wall component. 
Unfortunately, this cost comparison is not directly applicable to HUD-code manufactured housing. Although the building materials used are similar to the manufactured housing industry, labor constitutes only $14 \%$ to $20 \%$ of the total manufactured house cost versus approximately $50 \%$ for site-built construction and overall construction costs for manufactured homes are probably less than for site-built homes. It is assumed that the savings achieved by using foam panel components, listed in Table 4.2, were primarily obtained from a reduction in labor and construction time. However, these are tightly controlled factors in a factory setting.

TABLE 4.2. Cost Comparison of Foam Panel and Conventional Site-Built Construction

\begin{tabular}{|c|c|c|c|c|}
\hline Component & $\begin{array}{c}\text { Construction } \\
\text { Type }\end{array}$ & $\begin{array}{l}\text { Estimated } \\
\text { Total } \\
\text { R-Value }\end{array}$ & $\begin{array}{c}\operatorname{Cost}^{(a)} \\
(\$ / s f)\end{array}$ & Savings \\
\hline $2 \times 8$ Roof & $\begin{array}{l}\text { composition roofing/felt/ } \\
\text { truss/rafter/sheathing/ } \\
\text { insulation/vapor barrier }\end{array}$ & R30 - R33 & $\$ 6.82$ & - \\
\hline $\begin{array}{l}\text { 8" Roof }^{\prime \prime} \\
\text { Panel }\end{array}$ & $\begin{array}{l}\text { composition roofing felt } \\
\text { truss/rafter/panels } \\
\text { ( } 7.5^{\prime \prime} \text { EPS core)/splines }\end{array}$ & R38 - R39 & $\$ 5.60$ & $\$ 1.20$ \\
\hline $2 \times 6$ Wall & $\begin{array}{l}\text { LP siding/sheathing/drywall/ } \\
\text { vapor barrier/ } 2 \times 6 \text { stud/ } \\
\text { insulation }\end{array}$ & R19 - R22 & $\$ 7.17$ & - \\
\hline $\begin{array}{l}6^{\prime \prime} \text { Wall } \\
\text { Panel }\end{array}$ & $\begin{array}{l}\text { LP exterior facing/ } \\
\text { drywall/panels ( } 5.5^{\text {" EPS }} \\
\text { core)/top and bottom plates/ } \\
\text { splines }\end{array}$ & R28 - R29 & $\$ 5.20$ & $\$ 1.93$ \\
\hline $2 \times 8$ Floor & $\begin{array}{l}\text { sheathing/floor joists/ } \\
\text { insulation }\end{array}$ & R30 - R33 & $\$ 4.84$ & - \\
\hline $\begin{array}{l}8^{\prime \prime} \text { Floor } \\
\text { Panel }\end{array}$ & $\begin{array}{l}\text { panels ( } 7.5^{\mathrm{a}} \text { EPS core)/ } \\
\text { splines }\end{array}$ & R38 - R39 & $\$ 4.03$ & $\$ 0.81$ \\
\hline Cost & udes contractor's profit and $i$ & alled labor. & & \\
\hline
\end{tabular}


Studies by the University of Central Florida (UCF) provide very recent data and insights about foam panel costs. UCF's Industrial Engineering Department is a member of DOE's Industrialized Housing Program, whose goal is to increase the energy-efficiency of industrialized housing through research and technology transfer. One task to achieve this goal is a Process and Energy Efficiency Review (PEER) visit to an industrialized housing manufacturing plant to evaluate the design and manufacturing process. UCF has developed a prototype simulation program they use on the PEER visits to model the plant's production process. All the data collected from the PEER visits are incorporated into the simulation model.

Table 4.3 lists the estimated costs, based on a PEER visit, for a fully finished standardized wall ( 40 foot wide by 8 foot high) for various site-built construction technologies. Each manufacturer was in a different geographic location causing variations in labor and material costs. Note that cost was used as the primary benchmarking criterion, instead of price, to permit an objective comparison of actual resource requirements (labor, materials, capital, facilities, and equipment) between wall-building technologies. The "Total Cost" row shows that foam panels are $25 \%$ to $56 \%$ more expensive than both site-built and factory-framed construction based on the specific cases examined. The main difference is the high capital and indirect foam panel costs resulting from low factory utilization, excess floor space, and high inventory levels.

UCF adjusted the analysis for equivalent capacity utilization and inventory assumptions. These results are shown in the row labeled "Total Adjusted Cost" in Table 4.3. Under these conditions, the cost competitiveness of foam panel construction improved considerably, bringing it within about $18 \%$ of the cost of conventional construction. These results suggest that this technology may have comparable costs once the panel producers are able to operate closer to continuous operation and full utilization, which would be the case if they supplied foam panels to a manufactured housing plant. The total adjusted foam panel cost is about $\$ 5.00$ per square foot, which falls between the un-cut and pre-cut cost.

Unfortunately, enough data do not exist to approximate the foam panel cost for manufactured housing since no other building industry requires continuous highvolume quantities. A demonstration project and detailed cost analysis are necessary to quantify the labor and material costs, and the production level impacts. 
Table 4.3. Cost Comparison for Various Wall Construction Types

\begin{tabular}{|l|c|c|c|c|c||}
\hline Cost Component & $\begin{array}{l}\text { 4" Wall, } \\
\text { Site-Built, } \\
\text { MFR 1 }\end{array}$ & $\begin{array}{l}\text { 4" Wall, } \\
\text { Factory } \\
\text { Framed, } \\
\text { MFR 2 }\end{array}$ & $\begin{array}{l}\text { 4" Wall, } \\
\text { Factory } \\
\text { Framed, } \\
\text { MFR 3 }\end{array}$ & $\begin{array}{l}\text { 4" Wall, } \\
\text { Foam } \\
\text { Panel, } \\
\text { MFR 4 }\end{array}$ & $\begin{array}{l}\text { 4" Wall, } \\
\text { Foam } \\
\text { Panel, } \\
\text { MFR 5 }\end{array}$ \\
\hline \hline Material & 970 & 970 & 940 & 1060 & 1090 \\
\hline Labor & 380 & 330 & 380 & 440 & 450 \\
\hline Capital \& Indirect & 0 & 60 & 40 & 600 & 150 \\
\hline Total Cost & $\$ 1350$ & $\$ 1360$ & $\$ 1360$ & $\$ 2100$ & $\$ 1690$ \\
\hline \hline $\begin{array}{l}\text { Total Adjusted } \\
\text { Cost }\end{array}$ & $\$ 1350$ & $\$ 1370$ & $\$ 1360$ & $\$ 1600$ & $\$ 1590$ \\
\hline \hline Source: (b) & & & & & \\
\hline
\end{tabular}

\subsection{POTENTIAL FOAM PANEL COST REDUCTIONS}

From the cost comparisons discussed in the previous section, foam panels are cost competitive, or nearly cost competitive, with conventional construction. Foam panel construction cost data specific to the HUD-code industry were unavailable, making it difficult to draw any conclusions. However, there are factors unique to manufactured housing that could result in a cost reduction.

If foam panels were used in manufactured housing, the annual volume could possibly exceed a typical foam panel plant's production capacity. For example, a typical double-wide manufactured home with dimensions 28 foot wide by 50 foot long, has approximately $1200 \mathrm{ft}^{2}$ of gross wall area. A typical Northwest manufactured housing plant production rate is approximately 1000 homes per year which would translate into 1.2 million $\mathrm{ft}^{2}$ of wall area per year, per plant. Assuming foam panels were also used for the floor and roof, the annual volume would increase to approximately 4 million $\mathrm{ft}^{2}$ per year, per plant. Such enormous quantities could dramatically reduce the foam panel cost.

(b) Personal communication with Mike Mullens of the University of Central Florida, Industrial Engineering Department. March 19, 1993. 
Ideally, the foam panel plant would be located next door to the HUD-code factory to reduce transportation costs. The foam panel plant would probably be producing at full capacity just to meet the demand for the HUD-code manufacturer. Since foam panel fabrication is rather straightforward, it is also feasible that the HUD-code producer would manufacture the panels on-site. Table 4.4 and Table 4.5 list a cost breakdown for a foam panel 4 feet wide by 8 feet high. In Table 4.5, the overhead and profit margin accounts for approximately $33 \%$ of the total panel cost. If foam panels were manufactured at the HUD-code factory, overhead and profit margins would be included in the total cost. However, as a result of the high production volume, the overhead, material, and labor costs could be significantly reduced.

A materials reduction is another area that could make foam panels cost competitive for manufactured housing. Currently, foam panels consists of a foam core with two structural facings, usually OSB. This replaces the stud framing, insulation, and exterior sheathing if applicable. Gypsum wallboard is placed on the interior side of the walls and ceiling to provide a 15-minute fire rating required by most building codes. A material like FiberBond, a structural gypsum wallboard manufactured by Louisiana-Pacific, could replace the interior foam panel facing and gypsum wallboard, reducing material and manufacturing costs. Although cost data were not collected for the FiberBond product, it would eliminate the need for standard gypsum which could represent a cost savings.

Table 4.4. $\quad 4^{\prime} \times 24^{\prime}$ Foam Panel Facing Cost Breakdown

\begin{tabular}{||l|c|}
\hline \hline Facing Component & Cost $^{(a)}$ \\
\hline \hline $7-1 / 16^{\prime \prime}$ OSB & 41.28 \\
\hline $7-1 / 16^{\prime \prime}$ OSB & 41.28 \\
\hline Glue & 8.64 \\
\hline Glue & 8.64 \\
\hline Labor & 34.56 \\
\hline \hline Sub-Total & 134.40 \\
\hline \hline (a) $\quad \begin{array}{l}\text { Prices effective April 21, 1993. Subject to change } \\
\text { without notice. }\end{array}$ \\
\hline \hline \multicolumn{2}{|c|}{ U.S. Building Panels inc., Tacoma, WA. } \\
\hline
\end{tabular}


Table 4.5. $\quad 4^{\prime} \times 24^{\prime}$ Foam Panel Cost Breakdown

\begin{tabular}{|l|l|l|l||}
\hline Foam Size & $3-5 / 8^{\prime \prime}$ & $5-5 / 8^{\prime \prime}$ & $7-3 / 8^{\prime \prime}$ \\
\hline Panel Size & $4^{\prime \prime}$ & $6^{\prime \prime}$ & $8^{\prime \prime}$ \\
\hline \hline Foam Cost & 46.08 & 71.04 & 92.16 \\
\hline Facing Cost (a) & 134.40 & 134.40 & 134.40 \\
\hline \hline $\begin{array}{l}\text { Material \& Labor } \\
\text { Sub-Total }\end{array}$ & 180.48 & 205.44 & 225.56 \\
\hline Overhead \& Profit & 89.34 & 101.70 & 111.65 \\
\hline \hline Total Cost & 269.82 & 307.14 & 337.21 \\
\hline $\begin{array}{l}\text { Material \& Labor } \\
\text { Cost/S.F. }\end{array}$ & 1.88 & 2.14 & 2.35 \\
\hline Total Cost/S.F. & 2.82 & 3.20 & 3.51 \\
\hline \hline (a) See Table 4.4 for cost breakdown. \\
\hline \hline Source:
\end{tabular}




\subsection{FOAM PANEL INDUSTRY}

Since foam panels were introduced into the building industry, during the 1950s, the foam panel industry has displayed steady growth and market penetration. However, the technology is far from becoming a common building method. Industry associations can provide the necessary support to increase foam panel market penetration.

\subsection{INDUSTRY ASSOCIATIONS}

The foam panel industry has encountered questions from the building industry concerning performance, production capacity, quality control, and the lack of general awareness of the technology. The Structural Insulated Panel Association (SIPA) was established in 1990 to advance the interests of structural panel producers and their suppliers and customers through programs of information dissemination, publicity, and membership technical support (Bruno 1992, p. 26). The association has 92 active members representing approximately $85 \%$ of the U.S. foam panel business (Baker 1992, p. 2).

Premier Building Systems, a manufacturer of Association of Foam Manufacturers (AFM) R-Control brand panels, is the only Pacific Northwest regional foam panel manufacturer SIPA member. According to other regional manufacturers, there is currently no direct membership benefit since most of the meetings and conferences are held in the eastern United States where there is a large concentration of manufacturers (see Figure 5.1). Regional manufacturers did express interest in establishing a regional chapter. 


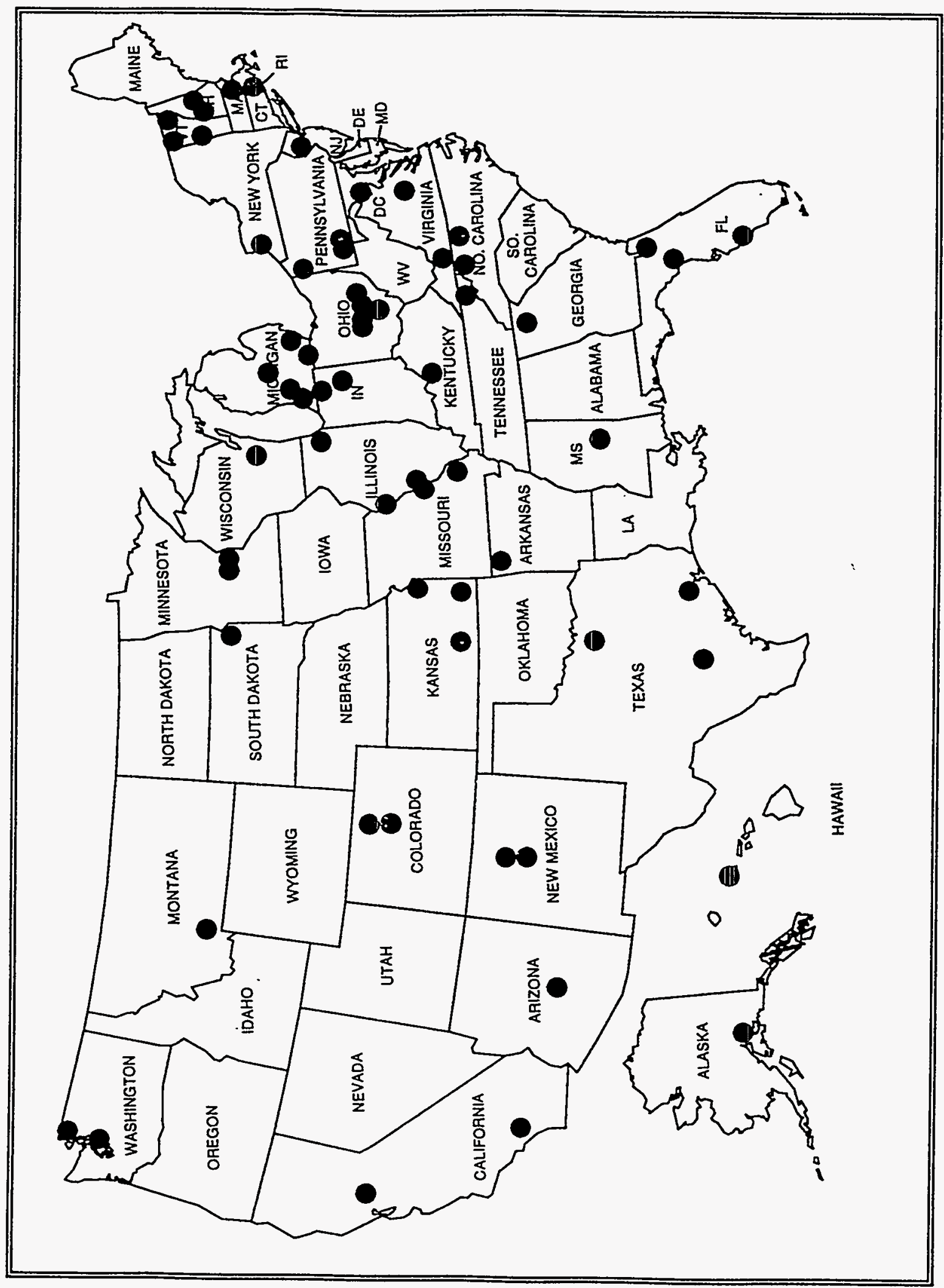

FIGURE 5.1. Geographic Location of Foam Panel Manufacturers Source: Andrews 1992a p. 120 


\subsection{MARKET POTENTIAL}

In 1991, SIPA sponsored a market potential survey of the wood-based foam panel industry for residential and light commercial buildings. Market production of wood-faced foam panels for 1991 was 15 million square feet, a $40 \%$ increase since 1988. Comfort, quality, energy efficiency, and greater market visibility appear to be the major driving forces behind the residential sector growth. Theoretically, a mature market could absorb an annual production of approximately 2.2 billion square feet, or 150 times the current production level (Steven Winter Associates 1991, p. 2-1). However, this production forecast does not include the manufactured housing industry. If foam panels were used only for the wall components in manufactured housing, the 19 regional HUD-code producers alone would require approximately 17 million square feet of foam panel per year: a 100\% increase over the 1991 national wood-faced foam panel production level. If foam panels were used for the wall, roof, and floor components, the regional HUD-code producers would require approximately 58 million square feet per year: a 400\% increase over the 1991 level. ${ }^{(a)}$ The high volume manufactured housing industry has the potential to dramatically impact the foam panel market potential.

Passage of the Energy Policy Act of 1992 will encourage a move toward tougher state energy codes which should stimulate foam panel sales. However, markets with inexpensive energy and labor will be difficult to penetrate. One of the biggest market growth obstacles is an inadequate understanding of the technology (Steven Winter Associates 1991, p. 2-2). The historical production growth indicates that structural panels could revolutionize the building materials market. Superior thermal performance and the escalating role of the volatile timber market will be important driving forces.

(a) Estimation assumes the 19 HUD-code plants in Washington, Oregon, and Idaho produce approximately 14,500 units per year. Typical unit characteristics include a double-wide with dimensions 28 foot wide by 50 foot long, a 7-1/2 foot wall height, and a 3:12 roof pitch. 


\subsection{NATIONAL FOAM PANEL MANUFACTURERS}

The focus of this study was the Pacific Northwest; however, only four panel manufacturers are located in this region and all manufacture EPS wood-faced panels. To expand this preliminary study, 20 other manufacturers were contacted and information was collected on other foam types, facing materials, and connection methods. Technical information was collected from the foam panel manufacturers listed in Table 5.1.

TABLE 5.1. Selected National Foam Panel Manufacturer Data Base

\begin{tabular}{|l|l|l|l|l|l||}
\hline Manufacturer & \multicolumn{1}{|c|}{ Location } & \multicolumn{1}{|c|}{$\begin{array}{c}\text { Foam } \\
\text { Type }\end{array}$} & \multicolumn{1}{|c|}{$\begin{array}{l}\text { Face } \\
\text { Type }\end{array}$} & $\begin{array}{l}\text { Connection } \\
\text { Method }\end{array}$ & SIPA \\
\hline Alchem & Anchorage, AL & Urethane & OSB & Spline & No \\
\hline $\begin{array}{l}\text { ALH Building } \\
\text { Systems }\end{array}$ & Markle, IN & EPS & OSB & -- & No \\
\hline Aliquot & Metamora, IL & Urethane & Fiberglass & $\begin{array}{l}\text { Tongue \& } \\
\text { Groove }\end{array}$ & No \\
\hline $\begin{array}{l}\text { APC } \\
\text { International }\end{array}$ & Auburn, WA & EPS & OSB & Spline & No \\
\hline Atlas Industries & Ayer, MA & $\begin{array}{l}\text { EPS } \\
\text { IsOcyan. }\end{array}$ & OSB & Spline & Yes \\
\hline $\begin{array}{l}\text { Concept 2000 } \\
\text { Homes }\end{array}$ & Dittmer, MO & EPS & OSB & Spline & No \\
\hline Elite Buildings & Sterling, CO & Urethane & Metal & Fastener & No \\
\hline Enercept & Watertown, SD & EPS & OSB & Spline & Yes \\
\hline $\begin{array}{l}\text { Enviro } \\
\text { Buildings }\end{array}$ & Quincy, IL & $\begin{array}{l}\text { EPS } \\
\text { XEPS } \\
\text { Urethane }\end{array}$ & Metal & Cam-lock & No \\
\hline $\begin{array}{l}\text { Fiber-Tech } \\
\text { Industries }\end{array}$ & Spokane, WA & $\begin{array}{l}\text { EPS } \\
\text { Urethane } \\
\text { PVC }\end{array}$ & $\begin{array}{l}\text { Fiberglass } \\
\text { plywOod }\end{array}$ & Spline & Yes \\
\hline Futurebilt & Wimberley, TX & EPS & OSB & Spline & Yes \\
\hline
\end{tabular}




\begin{tabular}{||l|l|l|l|l|l||}
\hline Manufacturer & \multicolumn{1}{|c|}{ Location } & \multicolumn{1}{|c|}{$\begin{array}{c}\text { Foam } \\
\text { Type }\end{array}$} & \multicolumn{1}{|c|}{$\begin{array}{c}\text { Face } \\
\text { Type }\end{array}$} & $\begin{array}{l}\text { Connection } \\
\text { Method }\end{array}$ & SIPA \\
\hline $\begin{array}{l}\text { Insteel } \\
\text { Construction } \\
\text { Systems }\end{array}$ & Brunswick, GA & EPS & $\begin{array}{l}\text { Concrete } \\
\text { W/ steel } \\
\text { mesh }\end{array}$ & - & No \\
\hline Insulspan & St. Louis, MO & EPS & OSB & Spline & No \\
\hline Korwall & Arlington, TX & EPS & OSB & Spline & Yes \\
\hline Murus Co. & Mansfield, PA & Urethane & OSB & Cam-lock & Yes \\
\hline $\begin{array}{l}\text { Panels } \\
\text { International } \\
\text { Inc. }\end{array}$ & $\begin{array}{l}\text { Federal Way, } \\
\text { WA }\end{array}$ & EPS & OSB & Spline & No \\
\hline $\begin{array}{l}\text { Premier } \\
\text { Building } \\
\text { Systems }\end{array}$ & Kent, WA & EPS & OSB & Spline & Yes \\
\hline $\begin{array}{l}\text { URSA } \\
\text { Structural } \\
\text { Systems }\end{array}$ & Yakima, WA & EPS & OSB & Spline & No \\
\hline Winter Panel & Brattleboro, VT & $\begin{array}{l}\text { EPS, } \\
\text { Urethane }\end{array}$ & OSB & Spline & Yes \\
\hline $\begin{array}{l}\text { W.H. Porter } \\
\text { Wolland, MI }\end{array}$ & $\begin{array}{l}\text { EPS, } \\
\text { Urethane }\end{array}$ & OSB & Spline & Yes \\
\hline
\end{tabular}




\subsection{REGIONAL FOAM PANEL MANUFACTURER SURVEY}

The Pacific Northwest foam panel manufacturers, listed in Table 6.1, were contacted either by site visit, phone, or mail. A questionnaire was administered to gather information in the following areas: company background, sales, customer information, product specifications, manufacturing and transportation, and the HUDcode manufactured housing industry. U.S. Building Panels and Panels International were not contacted in time to complete a questionnaire.

TABLE 6.1. Pacific Northwest Foam Panel Manufacturers

\begin{tabular}{||l|l|l||}
\hline \hline Manufacturer & Location & Phone Number \\
\hline \hline APC International & Auburn, WA & (206) 735-5709 \\
\hline Panels International, Inc. & Federal Way, WA & (206) 946-8747 \\
\hline $\begin{array}{l}\text { Premier Building Systems } \\
\text { (AFM R-Control) }\end{array}$ & Kent, WA & (206) 251-9277 \\
\hline URSA Structural. Systems, Inc. & Yakima, WA & (509) 248-6560 \\
\hline U.S. Building Panels, Inc. & Tacoma, WA & (206) 581-0288 \\
\hline
\end{tabular}

\subsection{COMPANY BACKGROUND}

All of the regional foam panel manufacturers produce EPS foam panels with panelized wood facings, predominately OSB. Other manufactured products include foam filled headers, wood headers, and non-structural panels. The regional manufacturers are conducting research and development in the areas of alternate panel materials, connection methods, and fabrication techniques. 


\subsection{SALES}

Over half of the foam panel manufacturer's sales are generated by sales representatives. Other methods include inquiries, trade shows, demonstration projects, advertisements, and video tapes. On average, the residential market represents approximately $75 \%$ of the foam panel sales for the regional producers. The retail, light commercial, and industrial sectors comprise the remaining sales. Two regional foam panel manufacturers have established international sales, primarily to developing countries.

\subsection{CUSTOMER INFORMATION}

Average percentages of regional foam panel sales by dollar volume are purchased by the following customer types: $35 \%$ builders, 30\% developers, $25 \%$ home owners (for retrofit), and $10 \%$ owner builders. Typical reasons for using the foam panel building system are, in decreasing significance, superior thermal performance, labor and cost savings, strength, durability, reduced lumber requirement, and increased air tightness. The majority of customers utilize foam panels for the roof, wall, and floor combined. Other typical combinations include the roof and wall, and the wall only. Services provided by the regional foam panel manufacturers include design specifications, total building design, technical assistance, tool loan, panel erection, shipping arrangement, and assistance in obtaining building permits.

\subsection{FOAM PANEL SPECIFICATIONS}

The regional foam panel producers use a one-pound-density EPS foam core. The two-pound-density foam is not cost-effective because the cost approximately doubles while the R-value only increases about $15 \%$. Typical materials offered for the interior and exterior facings respectively include OSB/OSB, OSB/T1-11 siding, gypsum/OSB which is non-structural, and gypsum and OSB/OSB. The foam panel manufacturers discourage the use of gypsum because it is easily damaged during transportation. Plywood is used to a lesser degree. The regional manufactures use three of the spline panel connection methods: double tongue and groove, two-by framing member, and thermally broken splines. Panel dimensions range from 4 to 8 foot wide, by 24 foot long, by 4 to 12 inches thick. Each foam panel manufacturer offers a warranty against panel delamination and the panels are sprayed with a pest repellant. The manufacturers have approval from the following organizations: ICBO, BOCA, SBCCI, HUD, Underwriters Laboratory (UL). 


\subsection{MANUFACTURING \& TRANSPORTATION}

None of the regional foam panel manufacturers produces the EPS at the factory site. Western Insulfoam and Northwest Foam are the dominant regional EPS suppliers. The foam panels are fabricated using a structural grade adhesive and cold press. Each manufacturer conducts quality control programs. The panel manufacturers offer finish work such as pre-cutting the panels and routing the foam for framing members, panel connection, and electrical chases.

\subsection{HUD-CODE MANUFACTURED HOUSING INFORMATION}

None of the foam panel manufacturers were aware of any prior or current use of foam panels in the HUD-code manufactured housing industry, although attempts have been made to penetrate the market. Foam panel manufacturers noted several advantages to the use of foam panels in manufactured-home construction:

Production occurs year-round and will require consistently large quantities of panels.

Foam panel technology is complementary to the quick construction time and low labor costs of the HUD-code industry.

The HUD-code market is large and growing and is unpenetrated by this technology

The foam panel manufacturers perceived some disadvantages as well:

Panel manufacturers are not familiar with the HUD-code industry and building techniques.

The building industry is resistant to change.

Panels are not cost competitive at this time. 


\subsection{DEMONSTRATION PROJECT INTEREST}

Two of the four foam panel manufacturers expressed interest in participating in a demonstration project. One option presented was a Cooperative Research and Development Agreement or CRADA. A CRADA is an agreement between a national laboratory, such as PNL, and one or more non-federal participants. Collaborators agree to share costs and results for a specific project. Data generated as part of a CRADA may be treated as proprietary for up to five years and the Freedom of Information Act does not apply. 


\subsection{REGIONAL HUD-CODE MANUFACTURER SURVEY}

PNL visited six regional HUD-code manufacturers listed in Table 7.1. These manufacturers represented a range of markets from the low-end through the more expensive high-end markets. The surveys were conducted with PNL staff meeting with the general manager and/or engineering manager. A questionnaire was used to determine the production and design impacts of using foam panels. The HUD-code manufacturers were given an informational packet that included product information from the regional foam panel manufacturers.

TABLE 7.1. Regional HUD-Code Manufacturers Surveyed

\begin{tabular}{|l|l|l|}
\hline Manufacturer & Location & Product Market \\
\hline \hline Fleetwood Homes of Oregon & Woodburn, OR & LOW END \\
\hline Redman Homes, Inc. & Silverton, OR & LOW END \\
\hline Fleetwood Homes of Washington & Woodland, WA & MEDIUM \\
\hline Guerdon Industries, Inc. & Stayton, OR & MEDIUM \\
\hline Moduline International, Inc. & Chehalis, WA & MEDIUM \\
\hline Glen River International & Centralia, WA & HIGH END \\
\hline \hline
\end{tabular}

\subsection{GENERAL IMPRESSIONS}

The majority of HUD-code housing manufacturers were familiar with the foam panel technology, but none had hands-on experience. No one knew of prior use of structural foam-core panels in the manufactured housing industry. Each manufacturer was very interested in learning more about the technology. Some of the "first impression" concerns include structural integrity, combustibility, and formaldehyde emissions. Foam panel manufacturer data were presented to address these issues. 


\subsection{FUNDAMENTAL CONCERNS}

All of the HUD-code manufacturers considered the following issues to be significant obstacles:

Transportation - Since the manufactured homes are transported on a "permanent foundation" or chassis, tremendous stresses are imposed throughout the entire structure during transportation. It is possible that the rigid foam panel building components would not allow adequate flexibility to alleviate the stresses.

Weight - It is unknown if the panels will increase or decrease the total weight of the house. With the additional insulation and materials required under the MAP, weight has become a critical factor. If the transported weight of the homes could be reduced, then one or more axles used during transportation could be eliminated, reducing cost and labor.

Resistance to change - It is not uncommon for the building industry to take five to ten years to implement a new technology. The manufactured housing industry can lag another five to ten years behind the site-built market, although the widespread introduction of vinyl windows through the Pacific Northwest's energy-efficient SGC program and MAP show that rapid changes are possible.

Lack of incentive - Builders are comfortable with established methods and are unwilling to take risks unless there is a customer demand or an obvious cost benefit. Currently, most Northwest HUD-code manufacturers are producing at their plant's capacity, which leaves little time to investigate alternative building techniques and materials. 


\subsection{PERCEIVED ADVANTAGES}

Some of the perceived advantages predicted by the HUD-code manufacturers are described below. The advantages are listed in decreasing order based on the cumulative responses.

1) Wood alternative - This was echoed from manufacturer to manufacturer. Many companies are already investigating alternatives to wood framing members such as steel studs. The HUD-code industry is extremely cost conscious making the recent lumber price fluctuations costly. There has also been a steady decline in the quality of the lumber, which has caused walls to buckle and the sheetrock to crack. These types of defects cost the manufacturers thousands of dollars. The repair and lumber costs must be recovered somewhere, usually by increasing the sale price of the home. If lumber prices continue to soar, foam panels could soon become cost competitive.

2) Allow use of less expensive windows - Under the current MAP specifications, the unlimited glazing option requires using vinyl-framed, argon-gas-filled, lowemissivity-coated windows. These are far more expensive than the typical double-glazed aluminum framed window used in manufactured homes. A foam panel wall could allow the use of less expensive windows without compromising the thermal integrity. Figure 7.1 is a graph showing the additional glazing area that would be possible with foam panel construction while maintaining the same wall $U^{(a)}$ value.

3) Increase interior volume - Currently, all of the Pacific Northwest manufactured home producers use vaulted truss ceilings. A foam panel roof is a true vault, where the interior slope is equal to the exterior slope (see Figure 7.2).

Transportation regulations restrict the exterior height of manufactured homes, therefore any increase in interior volume would have to be made from the interior side. Because foam panel roofs do not require trusses, they could provide approximately $4 \%$ more interior volume.

4) Materials reduction - Materials represent approximately $50 \%$ of the manufactured home cost. Even a materials cost reduction of $25 \%$ would correspond to a $12 \%$ total cost reduction, which is significant. Foam panels would reduce or eliminate batt and blown insulation, nails and staples, dimensional lumber, trusses, and exterior siding.

(a) The UA value is a measure of the total heat transmission with units of Btu / $\mathrm{ft}^{2}$ hour $F$. 
5) Labor savings - If the foam panel construction was fully integrated into the production line, the manufactured housing plant could increase its production capacity. There would be fewer materials to handle, less nailing, and quicker construction. But labor is only $14 \%$ to $20 \%$ of the manufactured home cost so even a $50 \%$ decrease in labor would only result in a $7 \%$ to $10 \%$ total cost reduction.

6) Production line oriented - Foam panels would easily integrate into a production line. There is also the potential for automation which does not exist for conventionally framed components. A computer-controlled production task, such as wall construction, would only require a few cuts for the foam panels; the wall height, length, and openings.

7) Minimal floor plan dimension modifications - Typical manufactured home dimensions are in 4-foot increments. Foam panels are also in 4-foot increments which is a junction of the panelized wood facing dimensions. Foam panels would require fewer cuts, making the process quicker and cheaper.

Manufactured homes are essentially boxes attached together; this is the ideal building type for foam panel construction.

8) Reduce sealing and caulking - Foam panels are inherently tight. They provide a continuously rigid surface. There are fewer cracks, defects, and leaks, which reduces the need for sealing and caulking.

9) Thermal performance - This is not as significant a benefit under MAP as it might otherwise be because thermal performance specifications for MAP homes are already exceedingly high. MAP requires an R-21 high density insulation batt in a $2 \times 6$ inch framed wall cavity. A typical 6 inch foam panel wall will provide an R-22 insulation level, only an R-1 increase for the same sized wall cavity. However, the R-value is not a complete indication of the thermal performance because thermal bridging and infiltration also influence thermal performance, which are reduced with foam panel construction.

10) Quality control - The quality will be improved because there are fewer construction steps. 


\subsection{PERCEIVED DISADVANTAGES}

Some of the perceived disadvantages the manufactured home producers predicted are listed below in decreasing order based on the cumulative responses.

1) Cost - The HUD-code industry is extremely sensitive to any cost increase. Unless the product is less expensive from the onset, then further consideration would be difficult to justify.

2) Wiring - The wiring procedure required for the foam panel construction is very different from the conventional procedure. It appears to be more labor intensive, at least initially. The electrical layout of the homes would have to be re-evaluated and a production line re-sequence would be necessary.

3) Unfamiliar technology - Lack of familiarity is a major impediment; none of the manufacturers had experience with foam panel construction. Customers are also unfamiliar with the technology and could perceive it as an inferior product.

4) Structural engineering and testing requirements - Extensive testing would be necessary to verify that foam panels are consistent with code requirements. The effects of transportation are critical factors.

5) Floor system redesign - The floor system would have to be redesigned if foam panels are used. The floor must accommodate the ducting and water lines. See Figure 7.3.

6) Limit or alter flexibility for customization - Currently, manufacturers offer standard floor plans and home designs. However, most customers request alterations such as additional window area or even shifting a wall. The current design process permits this flexibility and is an essential element to allow the buyer a limited degree of customization. It is possible that some design flexibility would be lost due to the foam panel structural properties.

7) Production line sequence alteration - To completely integrate panels would require a complete redesign of the production line, which would be expensive. 


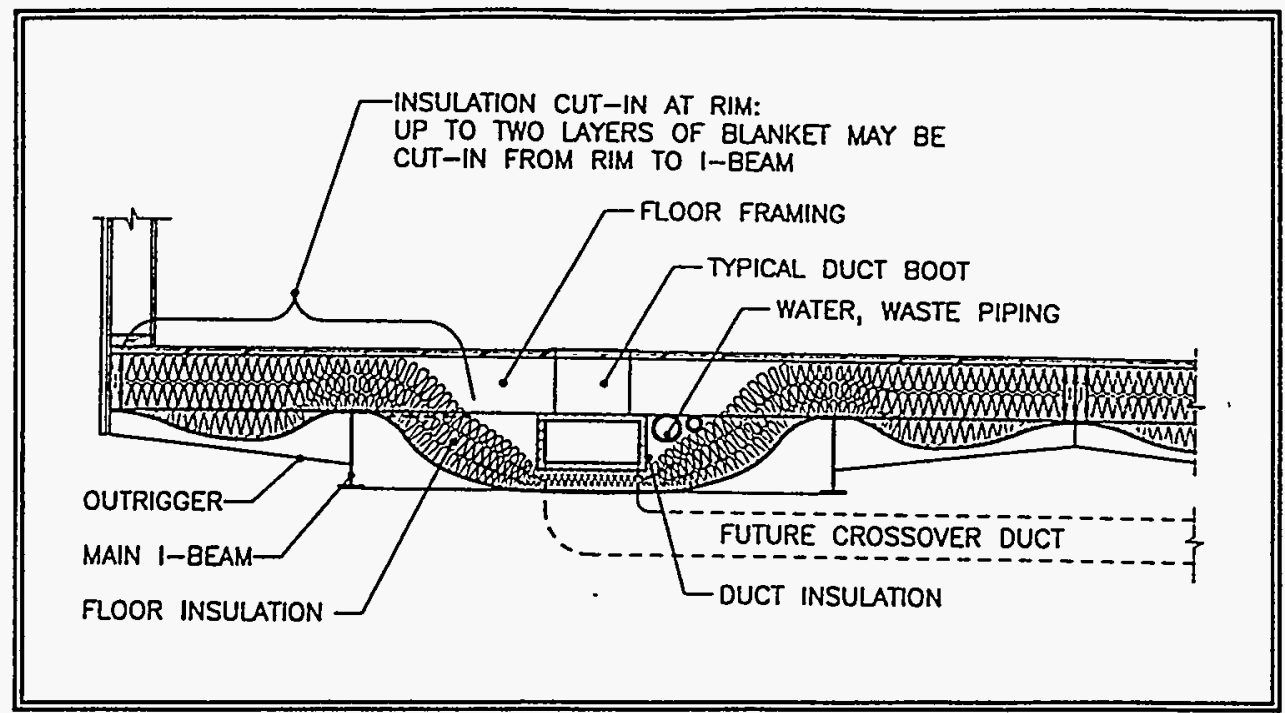

FIGURE 7.3. Manufactured Housing Transverse Floor Section Source: Bonneville Power Administration

\subsection{BUILDING COMPONENT FEASIBILITY}

During the site visits, we asked each manufacturer which building component would be most compatible with the foam panel system and why. Five of the six manufacturers responded.

Four of the manufacturers thought a foam panel wall system could be easily integrated into the current production line, except for the wiring. The labor would be reduced because frame wall construction is time consuming. The most significant advantage would be the use of less expensive windows without compromising the thermal performance.

Only one manufacturer thought that a foam panel roof would provide the greatest benefits. A foam panel roof would increase the interior volume because it provides a true vaulted ceiling. Ventilation would be unnecessary because foam panels roofs are essentially air-tight, eliminating air leakage associated with conventional frame construction. Unlike fiberglass batts, the closed cell foams are resistant to moisture absorption. There is the potential for a significant labor savings and materials reduction. The production line could be readily adapted to accommodate foam panels. 
All of the manufacturers considered the floor to be the most difficult to integrate with foam panel technology. The floor would have to be redesigned to accommodate the plumbing lines and heating ducts. Integrating foam panels into the floor construction would impact the entire production line because it is the first stage of production. The walls and roof are assembled to the side of the main production line.

\subsection{MANUFACTURING OBSTACLES}

If foam panels were used in HUD-code housing, they would reduce the need for framing members, insulation, exterior sheathing, and possibly gypsum wallboard. However, the storage space necessary for foam panels far exceed that needed for the conventional raw materials. According to Dennis Conlan, an engineering manager at the Florida Solar Energy Center, a HUD-code plant producing ten double-wide floors per day using conventional materials would require $670 \mathrm{ft}^{3}$ of storage space for the exterior wall raw material, preferably placed adjacent to the wall assembly line. Of this amount, $207 \mathrm{ft}^{3}$, or $30 \%$, is needed for insulation which can be stored overhead and does not occupy floor space. In comparison, one day's inventory of 4 " foam panel walls, plates, and splines would require $2,280 \mathrm{ft}^{3}$ of storage space, all at floor level. If $6^{\prime \prime}$ floor and 8" roof foam panels are added to this scenario, the total daily storage space required for wall, roof and floor panels, plates, and splines is $11,900 \mathrm{ft}^{3}$ versus $2,930 \mathrm{ft}^{3}$ for the conventionally framed raw materials. Typically, manufacturers maintain one to three weeks of production inventory. This would probably require an additional building to store the foam panel components.

\subsection{DEMONSTRATION PROJECT FEASIBILITY}

Most manufactured home producers would require substantially more information before they would commit to participating in a demonstration project. The most notable obstacle is the lack of manufacturer and customer familiarity with the technology. The producers are reluctant to take a risk on an unproven technology. They are very cautious when using new products because they feel that production failure could be costly and dangerous to their industry. 
Each manufactured home producer expressed concerns about cost effectiveness. Current foam panel costs are higher than conventional construction. Unfortunately the foam panel cost data available was insufficient to obtain a valid cost comparison. It is believed that there are some hidden incremental costs from conventional construction labor and materials that could help close the gap; however, a demonstration project would be necessary to identify and quantify these factors.

At least four of the manufactured home producers expressed concern about the structural integrity of the foam panel components. The HUD code structural requirements would have to be met first and then the effects from transportation would need to be analyzed. Although the manufacturers are interested in this technology, there is no incentive to pursue it.

Assuming the cost and design issues were resolved, half of the manufactured home producers expressed interest in becoming involved in a demonstration project, although all were interested in contributing their expertise. The manufactured housing plants that produce for the low end and medium price markets usually have very high production rates, with seven to ten floors produced per day. That level of production cannot afford any type of disruption. Integrating new products, workers, or equipment in a high production plant requires careful planning to minimize the interruption. Consequently, manufacturers with a slower production rate might be better suited to accommodate a demonstration of new technologies and products. 


\subsection{FOAM PANEL RESEARCH}

Research is important to advance any field. This is especially true of the foam panel industry because it is a relatively new technology and the construction industry is resistant to change.

\subsection{DOE'S ENERGY-EFFICIENT INDUSTRIALIZED HOUSING PROJECT}

The Energy-Efficient Industrialized Housing (EEIH) Project is a division of DOE's Industrialized Housing Program. The EEIH project goal is to "develop techniques to produce marketable industrialized housing that is $25 \%$ more energy-efficient than currently required by the most stringent U.S. residential codes and at less cost." Project members include the Center for Housing Innovation at the University of Oregon, which provides expertise in energy-efficient design and construction details; the Florida Solar Energy Center, which provides expertise in energy-efficiency evaluation; and the Department of Industrial Engineering at the University of Central Florida, which brings expertise in the area of industrial production processes (University of Oregon and Florida Solar Energy Center 1992).

For the EEIH project to achieve its goal, a variety of research and technology transfer tasks are conducted. One such task is a Process and Energy Efficiency Review (PEER) visit where the project team conducts an intensive two-and-a-half day review of an industrialized housing manufacturing plant's design and manufacturing processes, and an energy-efficiency evaluation of at least two model homes ${ }^{(a)}$. Recommendations are made to increase productivity and the energy-efficiency of the product (University of Oregon and Florida Solar Energy Center 1992).

\subsubsection{Penn Lyon Homes PEER Visit}

Penn Lyon Homes of Selinsgrove, Pennsylvania, is the sixth largest modular manufacturer in the United States. (Chandra et al. 1991). According to a Penn Lyon representative, Penn Lyon was investigating alternative technologies and materials to simplify its wall construction system. In addition, it was considering a line of energyefficient homes. Foam panels appeared to be a feasible option.

(a) Typical industrialized housing plants include panelized, modular, and HUD-code manufactures.

8.1 
A modular home utilizing EPS foam panel walls was designed, code approved, and constructed on its production line in 1991. Panels were not used in the floor or roof because this would have required additional testing and code approval. Tests were conducted to determine the load-bearing wall stresses induced during transportation. Results concluded that the panels are more rigid than a conventionally framed wall. Currently panel wall modular homes, focused at the high-end market, represent approximately $4 \%$ of Penn Lyon's sales.

In November 1991, a PEER visit was conducted at Penn Lyon Homes. Two ranch-style homes approximately $1,500 \mathrm{ft}^{2}$ were constructed in Penn Lyon's factory. One home was built using $2 \times 4$ inch framed walls while the other had R-Control EPS foam panel walls. The Florida Solar Energy Center tested each home with a blower door and infrared (IR) camera. A blower door test measures the building infiltration rate in air changes per hour (ACH) which is the amount of indoor air replaced with outdoor air in one hour. The American Society of Heating, Refrigerating and Air Conditioning Engineers (ASHRAE) recommends that a home maintain a natural infiltration rate of $0.35 \mathrm{ACH}$ to maintain good indoor air quality (ASHRAE 1989). An IR camera detects surface temperature differentials allowing you to "see through" the wall and detect heat loss paths and thermal anomalies.

The foam panel house had an infiltration rate of $0.33 \mathrm{ACH}$, which is slightly below the recommended standard. The conventional house had a rate of $0.65 \mathrm{ACH}$, about double the foam panel house leakage. The IR scan of the $2 \times 4$ inch framed home showed some missing insulation and thermal shorts at and around the studs. The IR scan of the foam panel house revealed an evenly distributed insulating surface with no thermal breaks. These test results "validate the excellent thermal performance of the foam-core panels ${ }^{\prime a}$.

a These test results were described in a trip report prepared by S. Chandra of Florida Solar Energy Center for DOE after visiting the Penn Lyon Homes factory in Selinsgrove, Pennsylvania on November 12-13, 1991. 


\subsubsection{Premier Building Systems PEER Visit}

In May 1992, another PEER visit was conducted at Premier Building Systems in Tacoma, Washington, in which PNL had the opportunity to participate. ${ }^{2}$ Premier manufactures AFM R-Control brand panels. Three R-Control foam panel homes were tested with a blower door and IR camera. The test results are summarized in Table 8.1.

TABLE 8.1. Infiltration Test Results of R-Control Foam Panel Homes

\begin{tabular}{|c|c|c|c|c|c|}
\hline \multirow{2}{*}{$\begin{array}{c}\text { Test House } \\
\text { Location }\end{array}$} & \multirow{2}{*}{$\begin{array}{c}\text { Floor Area } \\
{\left[\mathrm{ft}^{2}\right]}\end{array}$} & \multicolumn{3}{|c|}{ Component Construction } & \multirow{2}{*}{$\begin{array}{c}\text { Infiltration } \\
\text { (ACH) }\end{array}$} \\
\hline & & Walls & Roof & Floor & \\
\hline Olympia, WA & 1850 & Panel & Panel & Convt'l & 0.20 \\
\hline Rainier, WA & 1550 & Panel & Convt'I & Panel & 0.33 \\
\hline $\begin{array}{l}\text { Anderson } \\
\text { Island, WA }\end{array}$ & 1260 & Panel & Panel & Convt'l & 0.10 \\
\hline
\end{tabular}

The first house in Olympia, Washington, was an occupied home (see Figure 8.1). This house had R-Control foam panel walls and roof, and a conventionally framed floor. The house had electric heating registers and a wood stove. The blower door test resulted in an infiltration rate of $0.20 \mathrm{ACH}$. An air-to-air heat exchanger was installed to provide mechanical ventilation and heat recovery. An IR scan did not pick up any anomalies.

The next house tested was a new unoccupied spec home in Rainier, Washington, constructed by Collins Construction Company. It is shown in Figure 8.2. The walls and floor utilized foam panel construction. A forced air heating system was installed. The blower door test result was $0.33 \mathrm{ACH}$. The test indicated only a $2 \%$ leakage through the ducted forced-air heating system, which is excellent. It was concluded from the use of a smoke pencil that the recessed kitchen lights were the main leakage contributor. The IR scan did not indicate any significant leakage sites.

a PNL represented George James of The Office of Building Technologies, Conservation and Renewable Energy, U.S. Department of Energy. 
A new unoccupied vacation cabin on Anderson Island, Washington, constructed by GB Construction Company was the final test site (see Figure 8.3). This house utilized panel walls and roof, and a conventional floor. Heat was supplied by zonal electric registers and a wood stove. This house was very tight with only $0.10 \mathrm{ACH}$, which surprised the builder, who was on-site, since painstaking sealing measures were not taken. Not surprisingly, the IR scan did not indicate any thermal anomalies or insulation inconsistencies.

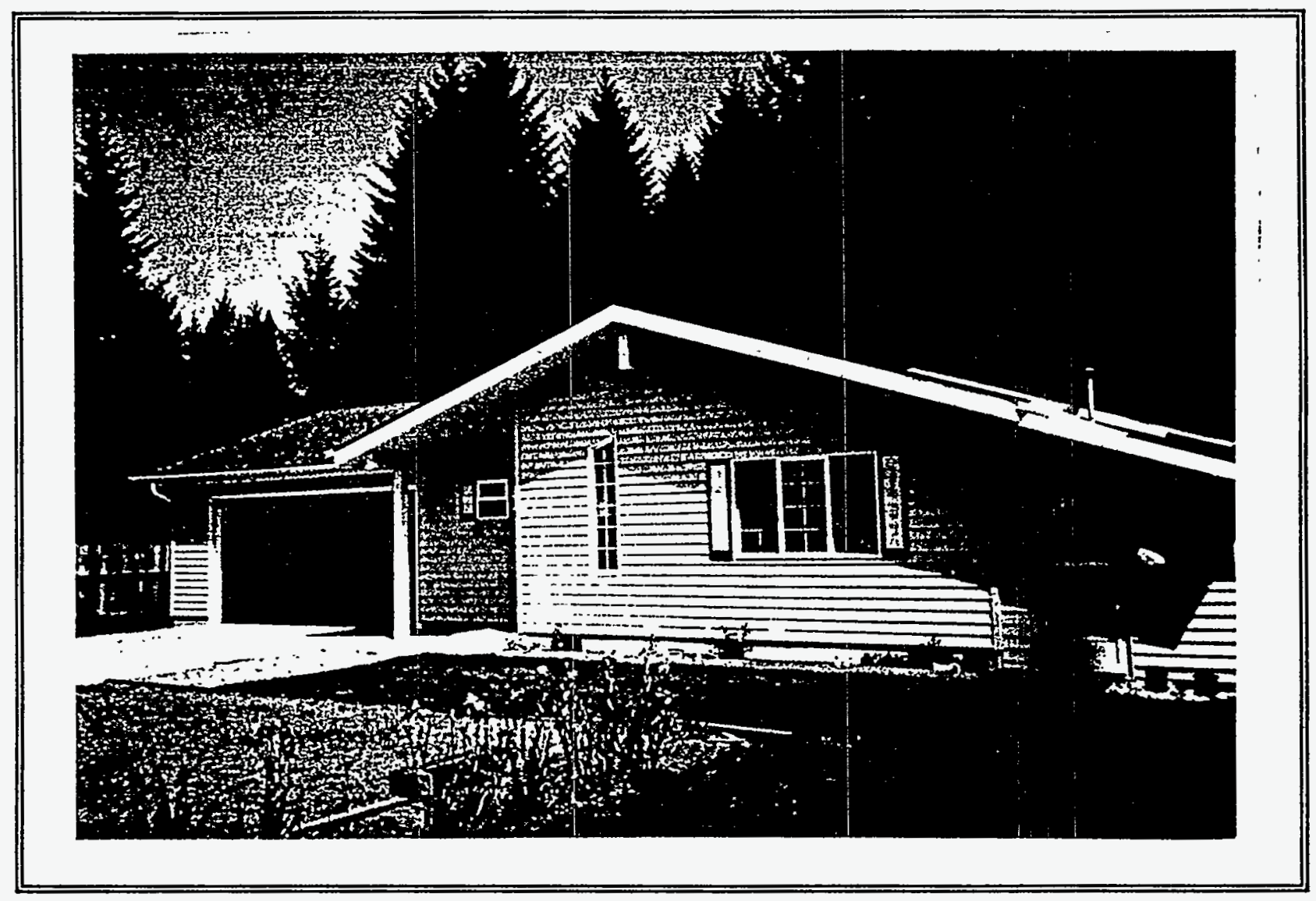

FIGURE 8.1. R-Control Foam Panel House, Olympia, WA 


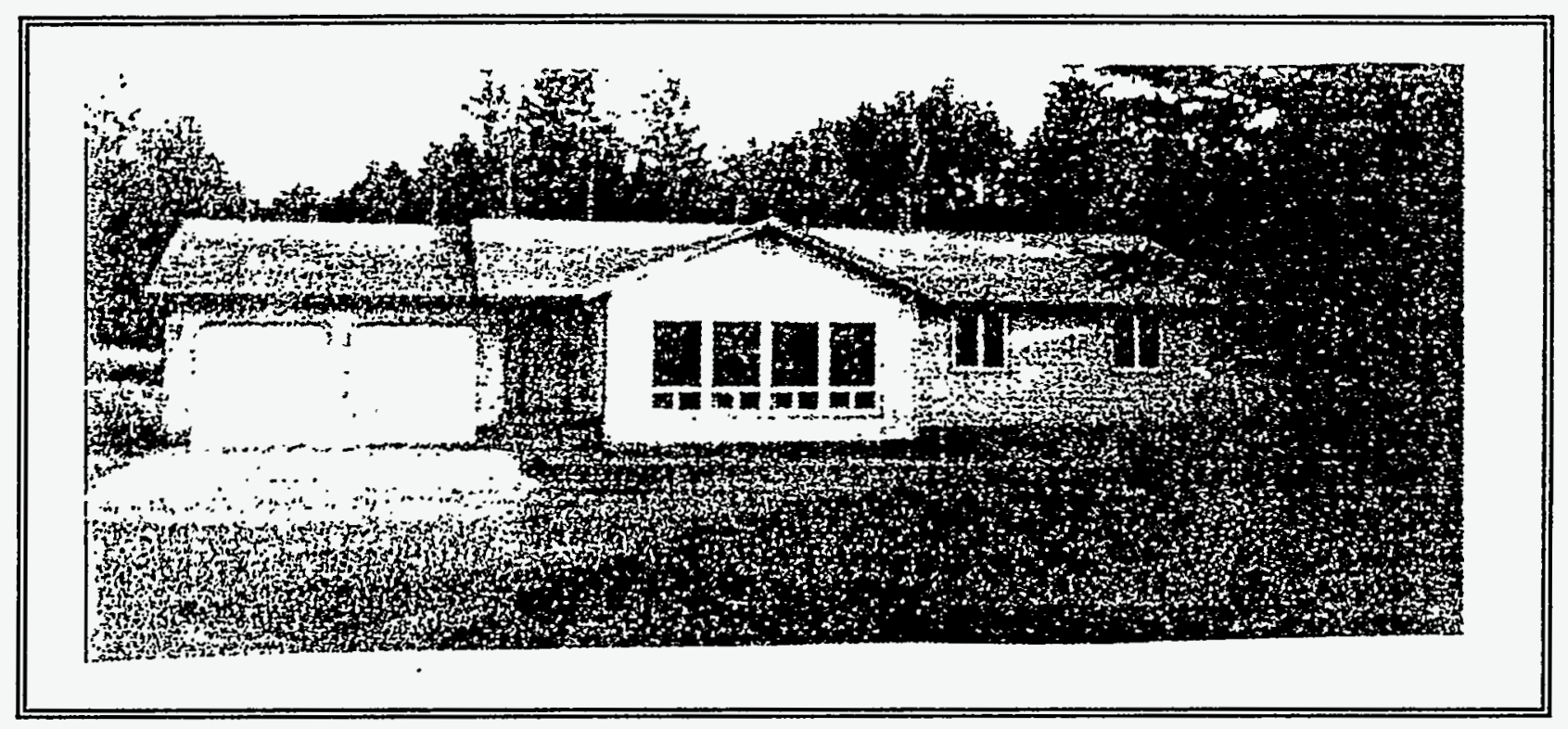

FIGURE 8.2. R-Control Foam Panel House, Rainier, WA

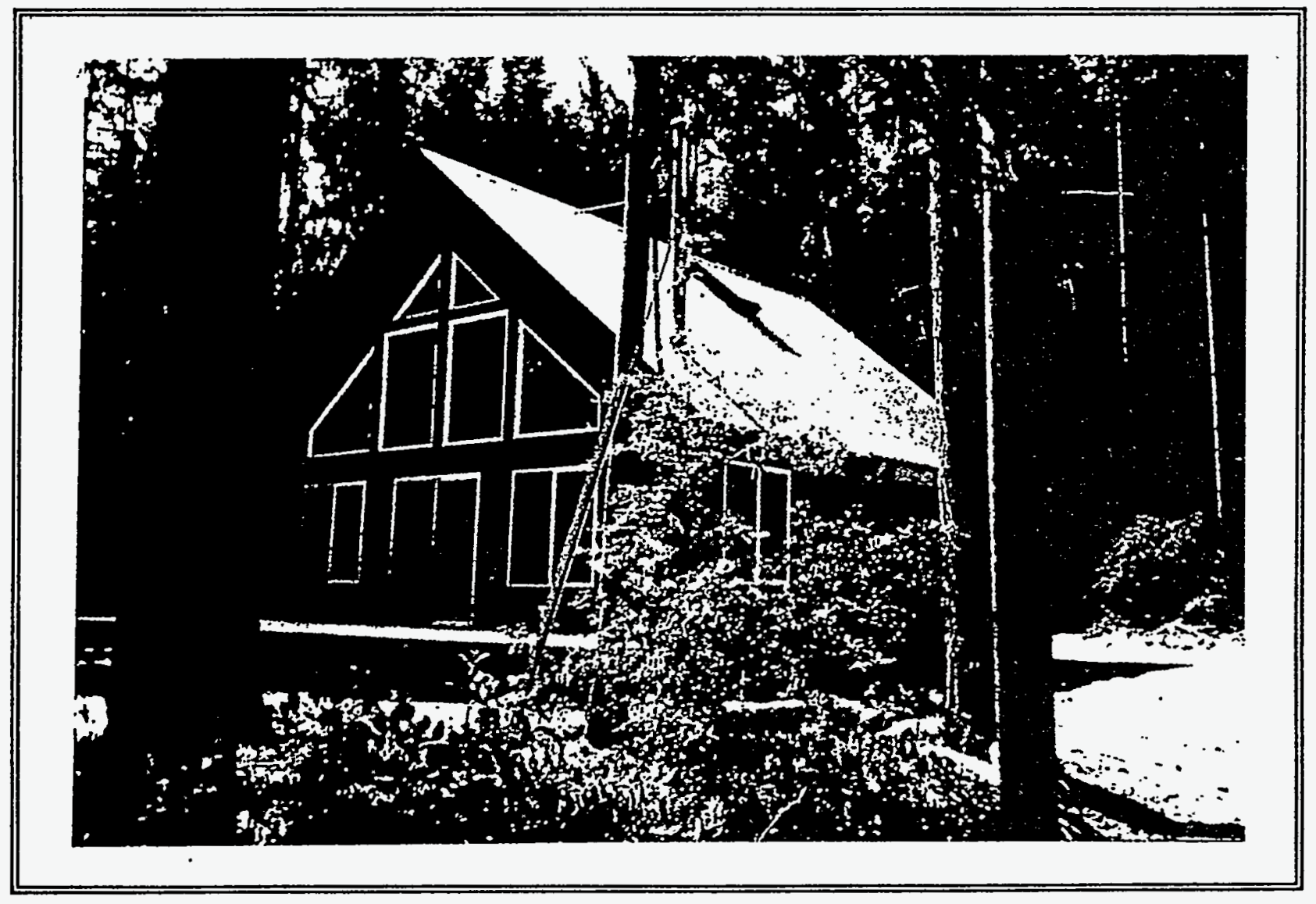

FIGURE 8.3. R-Control Foam Panel House, Anderson Island, WA 


\subsubsection{Side-By-Side Evaluation}

The foam panel industry association, SIPA, requested testing to assess the energy benefits of using foam panels in residential construction. The DOE-sponsored Industrialized Housing Program funded energy-use monitoring of two side-by-side houses built by Dovetail Construction in Louisville, Kentucky, one conventionally framed and the other using foam panels. Both houses have identical floor plans, heating systems, and approximately the same insulation levels. Detailed labor and material costs were obtained for each house during construction. Once the houses were completed and before they were occupied, building thermal performance testing and short-term energy monitoring was conducted by the Florida Solar Energy Center. Construction began in September 1992 and the monitoring took place during the winter of 1993 (Fischer 1992, p. 1).

The energy use results have been analyzed and released by the Florida Solar Energy Center. The calculated conductive thermal transmittance was within $2 \%$ for both houses. Co-heating data, a test procedure to measure the "as-built" total UA value, showed the foam panel house building load coefficient to be $12 \%$ lower then the frame house. Monitored heating energy-use data showed the foam panel house had a $12 \%$ and $15 \%$ nighttime energy-use reduction for electric and gas heating, respectively. An estimate of seasonal heating energy saving indicated a $14 \%$ to $20 \%$ savings for the foam panel house. Blower door, tracer gas, and infrared imaging tests indicated that both homes were very air-tight; however, the panel house had $30 \%$ less air infiltration than the frame house (Rudd 1993). These data provide an "apples to apples" comparison between conventional and foam panel construction. These test results one confirmation of what the foam panel industry has claimed, that foam panel construction reduces heating energy consumption and provides a near air-tight building shell.

\subsection{RECOMMENDED RESEARCH}

To completely assess the feasibility of using foam panels in HUD-code manufactured housing, a demonstration project is necessary. Only through the construction process will the production barriers and cost impacts be completely quantified. ideally, one or more demonstration houses would be sited, occupied, and monitored to evaluate the thermal performance. However, a demonstration project requires HUD-code manufactured housing producers willing to participate. 
Currently, there are too many questions related to the technology for a HUDcode home producer to assume all the risks of a demonstration project. Some of the risks can be reduced through continued research to expand this preliminary feasibility study by addressing issues such as compatibility with the HUD code and design options. A small-scale demonstration should then be initiated with one or more willing foam panel and HUD-code manufacturers who can benefit from participation. Other interested parties such as the DOE, HUD, and utilities should be partners in the demonstration. The initial demonstration should focus on how to better understand and resolve the fundamental concerns relating to the structural characteristics, production line and design impacts, and cost. A detailed cost analysis, thermal performance analysis, and design and construction analysis would provide the manufactured housing producers, and others, with reliable information to assess the cost and benefits of using structural foam-core panels in HUD-code manufactured housing. 


\subsection{CONCLUSIONS}

The results of this preliminary investigation indicate that additional research is necessary to sufficiently determine the potential for using structural foam-core panels in the HUD-code manufactured housing industry. Potential advantages indicated by the six regional HUD-code housing producers surveyed by PNL include a reduction in framing lumber, increased interior volume, the use of less expensive windows, and a simplified production process. The exceptional thermal performance provided by foam panels was a secondary concern to the regional HUD-code producers since they are currently building energy-efficient MAP homes. The advantages mentioned by the manufacturers were coupled with some fundamental issues that must be addressed before the technology can be thoroughly evaluated including the impacts on building structural integrity, production sequence, building design, transportation, and cost.

The manufactured housing industry provides quality affordable housing resulting from the production line construction process. As a result, manufactured home producers tend to be very cost conscious making cost-effectiveness a critical factor. Unfortunately, material and labor cost data relevant to the HUD-code industry are unavailable. If a foam panel manufacturer is not operating continuously at full capacity, which is often the case, then high inventory and overhead costs will increase the foam panel price. This would not be the case if foam panels were used in the manufactured housing industry where production continues year-round at highvolumes. If the foam panels were manufactured on-site, this could make them more cost competitive. Since cost is such a significant factor to this industry, a detailed cost-effectiveness analysis is necessary.

Ideally, a demonstration project that fully exploited the use of foam panels in manufactured housing would provide the opportunity to address the issues resulting from this study. Although the foam panel industry is interested and willing to supply materials and expertise, understandably the HUD-code manufacturers are unwilling to take risks on a product unproven in their industry that isn't currently cost-effective. However, the unstable lumber market in combination with dramatic price increases have left all builders considering framing alternatives as they realize there is not an unlimited supply of lumber. Foam panels could be a feasible and even cost-effective option. 


\subsection{REFERENCES}

76 FR 13590. May 6, 1976. "Manufactured Homes Procedural and Enforcement Regulations." Federal Register. Washington, D.C.

Andrews, S. March 1988. "Foam Panels. The Nuts, Bolts, and Bottom Line." Custom Builder, pp. 25-32.

Andrews, S. 1992a. Foam-Core Panels \& Building Systems. 2nd ed. Cutter Information Corp., Arlington, Massachusetts.

Andrews, S. February 1992b. "Building with Structural Foam Panels." Journal of Light Construction, pp. 13-17.

ASHRAE. 1989. 1989 ASHRAE Handbook of Fundamentals. American Society of Heating, Refrigerating and Air Conditioning Engineers, Inc., Atlanta, Georgia.

Baker, F. Fall 1992. "Message From the President." Spotlight on SIPA, p. 2.

Blair, K. January 1991. "Structural Insulated (Foam Core) Panels Industry Making Impact on Marketplace, Manufacturers Organize into Association." Automated Builder, pp. 12-13.

Blair, K. Fall 1992. "Quality Control of SIPs - The Role of the Third Party." Spotlight on SIPA, p. 3.

Bruno, A. June/July 1992. "Make Way for SIPs." Building Systems Builder, pp. 2428.

Building Systems Builder, p. 10. April 1993.

Chandra, S., P. Componation, R. Kellet, J. Mcllvaine, N. Moyer, M. Mullens, W. Swart. 1991. Energy-Efficient Industrialized Housing Process and Energy-Efficiency Review, prepared by the Center for Housing Innovation University of Oregon, the Florida Solar Energy Center, and the Industrial Engineering Department of the University of Central Florida for Penn Lyon Homes Corporation, Selinsgrove, Pennsylvania.

Chappell, S. Summer 1990. "Stresskin Panels: Where is the Technology Taking us?" Joiner's Quarterly, pp. 8-14.

10.1 
Energy Design Update, p. 12. May 1993.

Fischer, F. A. Fall 1992. "The Latest on Monitoring." Spotlight on SIPA, p. 1.

Hufnagel, J. March 1989. "Foam-Core Panels." Better Homes and Gardens, pp. 9093.

International Conference of Building Officials. 1977. Acceptance Criteria For Sandwich Panels, p. 3. International Conference of Building Officials, Whittier, California.

Louisiana-Pacific Corporation. 1993. FiberBond Fiber-Reinforced Gypsum Panels. Louisiana-Pacific Corporation, Portland, Oregon.

"Lumber Market Report." January 8, 1993. Random Lengths, p. 4.

Marshall and Swift. March 1993. Residential Cost Handbook. Marshall and Swift Co., Los Angeles, California.

Onisko, S.A. 1985. "Energy-Efficient Manufactured Housing." Bonneville Power Administration, Portland, Oregon.

Onisko, S.A., A.D. Lee. 1992. "Innovation in Manufactured Housing Energy-Efficient Programs." PNL-SA-20909.

Rudd, A., S. Chandra. June 1993. Side-By-Side Evaluation of a Stressed-Skin Insulated-Core Panel House and a Conventional Stud-Frame House. Florida Solar Energy Center, Cape Canaveral, Florida.

Steven Winter Associates, Inc. 1991. Market Potential for Structural Insulated Panels in Residential and Light Commercial Buildings. Prepared for the Natural Resources Research Institute, Duluth, Minnesota.

Structural Board Association. 1992. OSB and Waferboard in wood Frame Construction, U.S. Ed. Structural Board Association, Alpharetta, Georgia.

University of Oregon and Florida Solar Energy Center. 1992. Energy-Efficient Industrialized Housing Project Overview. Prepared by the University of Oregon Center for Building Technologies, Eugene, Oregon, and the Florida Solar Energy Center, Cape Canaveral, Florida for the Office of Building Technologies, Conservation and Renewable Energy, U.S. Department of Energy. 